\title{
WOVEN BONE OVERVIEW: STRUCTURAL CLASSIFICATION BASED ON ITS INTEGRAL ROLE IN DEVELOPMENTAL, REPAIR AND PATHOLOGICAL BONE FORMATION THROUGHOUT VERTEBRATE GROUPS
}

\author{
F. Shapiro ${ }^{1, *}$ and J.Y. $\mathrm{Wu}^{1}$ \\ Stanford University School of Medicine, Department of Medicine/Endocrinology, Palo Alto, CA, USA
}

\begin{abstract}
Cortical bone development is characterised by initial formation of woven bone followed by deposition of lamellar bone on the woven scaffold. This occurs in normal bone formation as an integral obligate selfassembly pattern throughout all vertebrate groups, with specific temporal and spatial features. It also occurs in repair bone, modified by the biophysical/mechanical environment, and in pathological bone, modified by the specific disorder and its severity. Two spatially distinct osteoblast cell populations synthesise woven and lamellar bone: mesenchymal osteoblasts surround themselves circumferentially with collagen in a random array to form woven bone; surface osteoblasts align themselves in a linear array on the woven bone surface (or adjacent lamellar bone) to synthesise parallel-fibred lamellar bone. Four specific stages of woven bone formation are defined: stage I, early differentiation of pre-osteoblasts from undifferentiated mesenchymal cells; stage II, mesenchymal osteoblasts surrounding themselves in a $360^{\circ}$ arc with randomly oriented matrix fibres; stage III, woven matrix acting as a scaffold on which surface osteoblasts begin to synthesise bone in parallel-fibred lamellar conformation; stage IV, progressive relative diminution of woven bone in the woven bone/lamellar bone complex. Stages II and IV are further subdivided (in $\mathrm{a}, \mathrm{b}$ and c) by shifting cell area/matrix area and woven bone/lamellar bone relationships. The under-appreciated biological significance of woven bone is that it initiates formation de novo at sites of no previous bone. This information allows for targeted assessment of molecular-biophysical mechanisms underlying woven bone formation and their utilisation for initiating enhanced bone formation.
\end{abstract}

Keywords: Woven bone, lamellar bone, mesenchymal osteoblasts, surface osteoblasts, woven bone structural classification, repair bone, pathological bone.

*Address for correspondence: Frederic Shapiro, MD, Stanford University School of Medicine, Department of Medicine/Endocrinology, 1651 Page Mill Road, Palo Alto, CA, 94304, USA.

Email: muskoka4@stanford.edu

Copyright policy: This article is distributed in accordance with Creative Commons Attribution Licence (http://creativecommons.org/licenses/by-sa/4.0/).

\section{Introduction}

Bone formation is characterised, at the tissue level and from the earliest embryological and foetal time periods, by an initial collagen matrix deposition in a randomly oriented pattern, referred to as woven bone, followed by collagen matrix deposition in a parallel orientation, referred to as lamellar bone. Woven to lamellar bone pattern, with lamellar bone synthesised on the woven bone scaffold, characterises normal cortical bone formation in all vertebrates. Not generally recognised are: i) the variable temporal and spatial patterns of woven bone replacement by lamellar bone across the entire vertebrate spectrum, including in extinct species, as defined by palaeohistology; ii) the integral role played by the initial synthesis of woven bone followed by lamellar bone formation not only for normal bone but also in repair and pathological bone formation; iii) the specific stages underlying woven bone formation. There is a tendency to refer to this initial bone formation in its woven conformation as only a brief transitional phase and, then, to concentrate bone tissue studies almost exclusively on the subsequent lamellar bone. Much information can be gained by assessing the unappreciated crucial role of the woven bone stage throughout vertebrate bone formation.

References to woven bone in overviews of bone biology are brief, reflecting the general consideration of woven bone as a transient structure of little 
significance (Buckwalter et al., 1995) and poor quality (Marotti, 2010). Jaffe (1929) presented an excellent introduction to woven bone and Frost (1960) provided interesting differentiating features from lamellar bone. Descriptions of bone structure have concentrated on its well-ordered lamellar component. Havers, over 300 years ago, described bone as composed of a series of lamellae running along the longitudinal axis of the bone cortices; intracortical blood vessels were observed but there was no mention of a specific relationship of the vessels to the lamellae (Havers, 1691). It was not until the mid1800s, with improved microscopy, that longitudinally oriented intracortical vessels surrounded by concentric lamellae were described and referred to as Haversian systems (Todd and Bowman, 1845). That terminology for the characteristic orientation of human cortical bone lamellae was widely adopted and refined in light microscopy studies outlining matrix structure, cells and vessels of the bone cortices but no specific mention of precursor woven bone was made (Quekett, 1849a; Quekett, 1849b; Tomes and de Morgan, 1853). Continuing studies illustrated the lamellar structure of mature human bone with Haversian system predominance (Kölliker, 1853; Kölliker, 1886; von Ebner, 1875).

Gegenbauer named the cells actively synthesising bone as "osteoblasts" and specifically referred to the initial bone tissue deposited as "Wurzelstock" (root-stock), now referred to in English as woven or

\section{Table 1a. Early descriptions of variable woven and lamellar bone orientation in vertebrate species.}

\begin{tabular}{|c|c|}
\hline Havers (1691) & $\begin{array}{l}\text { Described the bone structure as a series of "strings" of particulate matter, referred to as lamellae, running } \\
\text { along the longitudinal axis of bone cortices. "The bones...consist of several laminae, or thin plates, } \\
\text { lying one within or under another..."; "The bony particles form continued threads or strings; which } \\
\text { continuity gives the bones a rigidity. The course....of all the strings in the sides of a bone...(passes)... } \\
\text { from one end towards the other; and wherever the laminae which they make are contiguous, they are } \\
\text { parallel...and straight."; “...the strings laid in a convenient order and number form the plates (laminae) } \\
\text { and these plates make up the bone." In human and animal bone, arteries and veins in foramina passing } \\
\text { into marrow, bone pores and transverse and longitudinal passages were recognised. Havers did not } \\
\text { specifically describe blood vessels running longitudinally within the circular collections of lamellae } \\
\text { nor defined Haversian systems or osteons. }\end{array}$ \\
\hline $\begin{array}{l}\text { Todd and } \\
\text { Bowman } \\
(1845)\end{array}$ & $\begin{array}{l}\text { Described longitudinally oriented intracortical vessels passing through the centre of several surrounding } \\
\text { concentric lamellae. They were the first to refer to these structures in cortical bone as Haversian systems; } \\
\text { "the arteries and veins usually occupy distinct Haversian canals". }\end{array}$ \\
\hline $\begin{array}{l}\text { Tomes and De } \\
\text { Morgan (1853) }\end{array}$ & $\begin{array}{l}\text { Outlined matrix structure, cells and vessels of bone cortices; described formation of circular lamellae } \\
\text { surrounding individual longitudinal vessels within the cortex and referred to these as "Haversian } \\
\text { systems". }\end{array}$ \\
\hline & $\begin{array}{l}\text { Named the cells actively synthesising bone as "osteoblasts", with initial bone tissue deposited as } \\
\text { "Wurzelstock" (root-stock), referred to in English as woven or coarse-fibred bone. }\end{array}$ \\
\hline \begin{tabular}{l|} 
von Ebner \\
(1875), \\
Kölliker (1886) \\
\end{tabular} & $\begin{array}{l}\text { Recognised woven bone in their more detailed studies of bone formation; illustrated osteocyte cell } \\
\text { shape and patterns in lamellar cortical bone. }\end{array}$ \\
\hline \begin{tabular}{l|l} 
Gebhardt \\
$(1906)$
\end{tabular} & Described alternating fibre orientation in adjacent lamellae of human cortical bone. \\
\hline $\begin{array}{l}\text { Biedermann } \\
(1914)\end{array}$ & $\begin{array}{l}\text { Coined the term "osteon" (now used interchangeably with Haversian system): "...the unit dominated } \\
\text { by bone blood vessels, this concentrically structured bone area forms the ontogenetic and mechanical } \\
\text { single element (it could be called "the osteon") of all higher developed vertebrate bones." }\end{array}$ \\
\hline Foote (1916) & $\begin{array}{l}\text { Illustrated matrix and lacunar-canalicular patterns on cross-sections of femoral cortical bone throughout } \\
\text { vertebrates (amphibians, reptiles, birds and mammals, human included). Studied human bones of } \\
\text { various ages. No specific reference to woven bone. Defined intracortical structure as: } \\
\text { i) lamellar, uniform lamellae encircling the entire bone diameter [subdivided into } 3 \text { distinct forms: } \\
\text { uniformly concentric lamellae; two-fold division, with wide external and narrow internal lamellar } \\
\text { rings in contact; three-fold division, with } 3 \text { concentric rings (external narrow, central wide and } \\
\text { internal narrow)]; } \\
\text { ii) laminar, a larger and more complex bone layer characterised by laminae separated from adjacent } \\
\text { structures by vascular canals extending parallel to the long bone axis; } \\
\text { iii) Haversian systems (osteons), main structural units, with circumferential lamellae surrounding } \\
\text { a central longitudinal vessel, such as the one observed in higher mammals, including humans. } \\
\text { Some specimens combined all types; more than } 400 \text { complete cross-section drawings of histological } \\
\text { sections clarified accuracy of the descriptive terms. }\end{array}$ \\
\hline Jaffe (1929) & Defined coarse-fibred primary bone and fine-fibred lamellar bone. \\
\hline $\begin{array}{l}\text { Weidenreich } \\
(1930)\end{array}$ & $\begin{array}{l}\text { Defined woven-fibred, parallel-fibred and lamellar bone. In woven-fibred bone, collagen fibres are } \\
\text { arranged in a random fashion. In parallel-fibred bone, fibres run parallel to one another in the same } \\
\text { direction. In lamellar bone, the fibres are arranged in layers (the lamellae), with the fibres in each layer } \\
\text { having a specific orientation (different from adjacent layers). }\end{array}$ \\
\hline
\end{tabular}


Table 1b. More recent descriptions of tissue conformations in vertebrate cortical bone.

\begin{tabular}{|c|c|}
\hline Gross (1934) & $\begin{array}{l}\text { Oommented extensively on "Faserknochen" (fibre bone) and stressed its more frequent occurrence } \\
\text { vertebrate cortices than in postnatal human. Also described the variable matrix structure } \\
\text { atterns in vertebrate and fossil bone. }\end{array}$ \\
\hline $\begin{array}{l}\text { Enlow (1962), Enlow } \\
\text { and Brown (1956, } \\
1957,1958)\end{array}$ & $\begin{array}{l}\text { udied bone development throughout different vertebrate species and defined fossil bone } \\
\text { ructure in detail. }\end{array}$ \\
\hline Smith $(1960 a, 1960 b)$ & 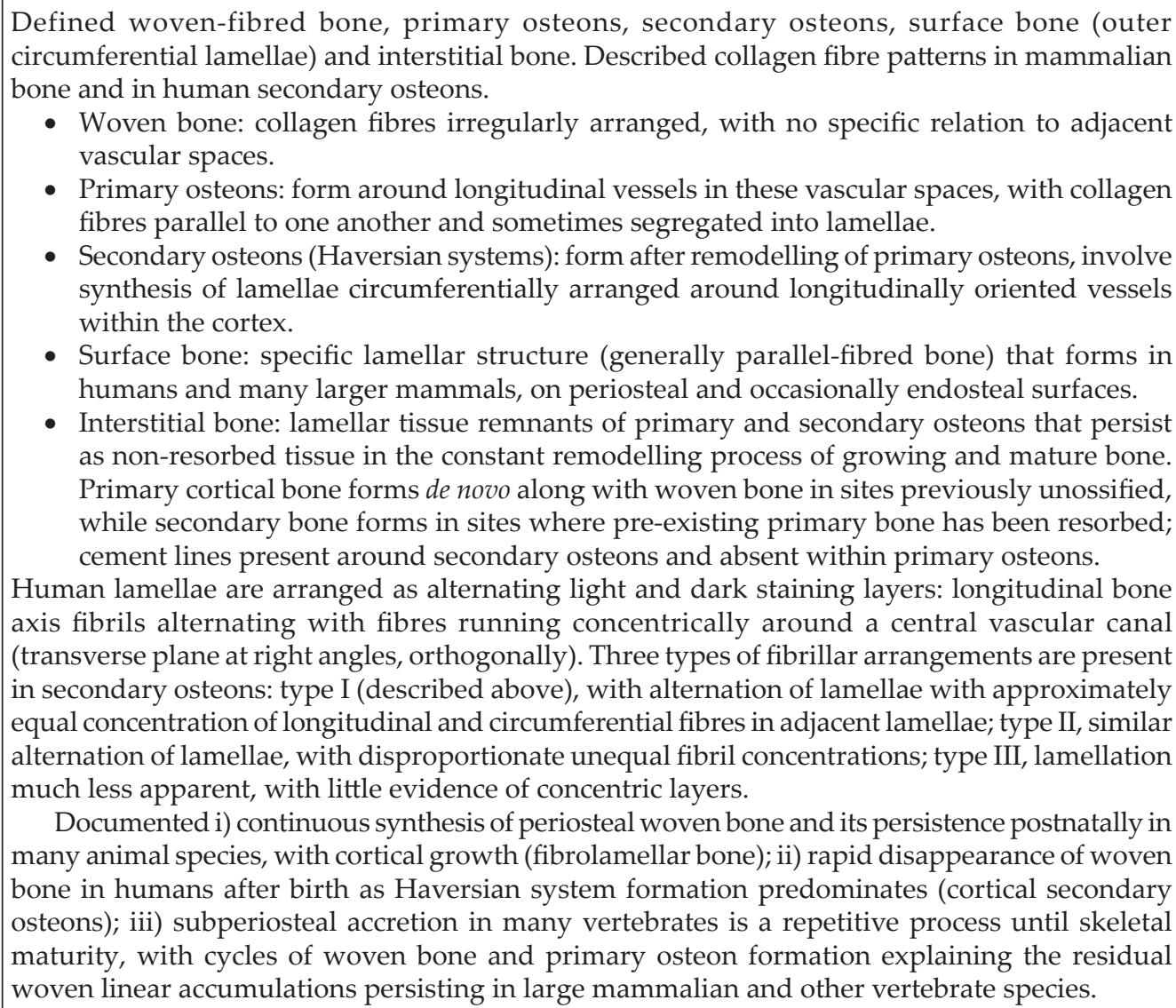 \\
\hline Cooper et al. (1966) & Presented a detailed assessment of the osteon morphology by transmission electron microscopy. \\
\hline $\begin{array}{l}\text { De Ricqlès (1975, } \\
\text { 1976) }\end{array}$ & $\begin{array}{l}\text { Refined the practice of paleohistology, introducing a classification and detailed descriptions of } \\
\text { diverse cortical bone tissue conformations throughout vertebrate fossils, that became the standard } \\
\text { for descriptive studies. Dense accumulations of Haversian bone, while being the common pattern } \\
\text { in human cortices, are the exception since other vertebrates, fossil and living, have wide structural } \\
\text { diversity. Classification pointed out persistence of fibrolamellar bone (woven bone surrounded by } \\
\text { parallel lamellar fibres) in developing postnatal and mature animals, along with primary, but far } \\
\text { fewer secondary, osteons. De Ricqlès and collaborators continued to assess vast numbers of species } \\
\text { in fossil and living vertebrate histology (Francillon-Vieillot et al., 1990; de Ricqlès et al., 2016). }\end{array}$ \\
\hline $\begin{array}{l}\text { Giraud-Guille } \\
\text { (1988), Giraud- } \\
\text { Guille et al. (2003) }\end{array}$ & $\begin{array}{l}\text { Working at the physical-chemical and ultrastructural level, identified the "twisted plywood" } \\
\text { pattern of collagen deposition in lamellar bone and further characterised the concept of collagen } \\
\text { matrix conformation as forming by self-assembly. }\end{array}$ \\
\hline
\end{tabular}

coarse-fibred bone (Gegenbaur, 1864; Gegenbaur, 1867). The formation, structure and continuous remodelling of bone at the tissue level have been the subject of detailed investigation: Jaffe defining coarsefibred primary bone and fine-fibred lamellar bone; Weidenreich defining woven-fibred bone, parallelfibred bone and lamellar bone; Smith defining wovenfibred bone, primary osteons, secondary osteons, surface bone and interstitial bone (Jaffe, 1929; Smith, 1960a; Smith, 1960b; Weidenreich, 1930). Table 1a,b detail the developing understanding of woven and lamellar bone in cortical bone formation.
There are several patterns of lamellar bone structure in vertebrate species. Foote, defining lamellar, laminar and Haversian system patterns of bone deposition, described: i) uniform lamellae encircling the entire diameter of the bone; ii) a more complex pattern characterised by laminae separated from adjacent structures by vascular canals; iii) multiple Haversian systems (osteons) in higher mammals, including humans (Foote, 1916). These differing patterns of lamellar bone organisation throughout vertebrate groups continue to undergo assessment, especially by palaeohistologists. The 
matter is pertinent to a discussion about woven bone since cortical lamellar bone made strictly of Haversian systems (osteons) is primarily restricted to humans and some large mammals. Most species show a persistence of fibrolamellar bone (where the fibro component is woven bone) due to repeated cycles of periosteal bone formation, where woven bone is repetitively synthesised after lamellar bone deposition rather than undergoing full resorption and complete secondary osteonal structuring. Differences in vertebrate cortical bone microstructure in multiple species and the variable terminology describing it are summarised in Table 2 and $3 \mathbf{a}, \mathbf{b}$.

The shape and orientation of osteoblasts and osteocytes and their cell processes change as extracellular matrices pass from woven to lamellar conformations. Developmental changes in the lacunar-canalicular system (housing cells and their processes, respectively) were identified early in the microscopical study of bone (Bidder, 1906; Gebhardt, 1906; Gegenbauer, 1864; Gegenbauer, 1867; Kölliker,1853; Quekett, 1849a; Quekett, 849b; Tomes and de Morgan,1853; von Ebner, 1875; Weidenreich, 1930). Osteoblast and osteocyte cell processes in canaliculi link adjacent cells through gap junctions (Burger and Klein-Nuland, 1999; Palumbo et al., 1990; Shapiro, 1988; Shapiro et al., 1995; Shapiro, 1997). The lacunar-canalicular system has structural and biomechanical implications (Currey, 2001) and serves as an accurate marker of cell activity in histological and palaeohistological assessments. Histological characteristics of woven and lamellar bone are detailed in Table 4.
Osteoblasts synthesising woven and lamellar bone are referred to using different terms to reflect their different modes of action. The osteoblast of woven bone is referred to as a mesenchymal osteoblast (MOBL), which surrounds itself in a $360^{\circ}$ arc with initially formed woven bone with randomly arrayed collagen fibres, while the osteoblast of lamellar bone is referred to as a surface osteoblast (SOBL), since it aligns in a linear array on the surface of woven bone to synthesise parallel-fibred lamellar bone (Shapiro, 1988; Shapiro, 2008; Shapiro, 2016). While all osteoblasts are considered mesenchymal in lineage, the term MOBL was chosen to indicate initial or de novo bone formation in a cellular mass where no bone previously existed, as would occur in the mesenchyme of classical embryological descriptive terminology. Marotti and colleagues have referred to woven bone formation as static osteogenesis and lamellar bone formation as dynamic osteogenesis (Ferretti et al., 2002; Marotti, 2010). The term static is used in their categorisation referring to the synthesis of woven bone occurring by differentiating cells surrounding themselves with matrix at a place where they are already present (hence static). The term dynamic is used to imply movement of cells to position themselves along bone surfaces where they synthesise lamellar bone. The cell population defined as MOBLs represents static osteoblasts while SOBLs represents dynamic osteoblasts. The terminology describing osteoblast synthesis of woven and lamellar bone formation is reviewed in Table $5 \mathbf{a}, \mathbf{b}$.

The present report outlines the deposition and structure of bone matrix from initial woven to eventual

Table 2. Differences between cortical bone structure in humans and other vertebrate species.

\begin{tabular}{|c|c|}
\hline $\begin{array}{l}\text { Primary and secondary } \\
\text { osteons }\end{array}$ & $\begin{array}{l}\text { Primary osteons form initially around blood vessels in woven bone; lamellar bone is laid down } \\
\text { circumferentially surrounding a central vessel to form the osteon. Secondary osteons form } \\
\text { following resorption of pre-existing bone and are distinguished structurally by surrounding } \\
\text { dense staining cement lines. Primary osteons differ from secondary osteons as there is no tissue } \\
\text { resorption accompanying their formation and no cement lines mark their extent. }\end{array}$ \\
\hline $\begin{array}{l}\text { Human foetal and } \\
\text { post-natal bone }\end{array}$ & $\begin{array}{l}\text { Study of humeral, femoral and tibial cortices show that: i) initially, early foetal woven bone } \\
\text { synthesised by inner osteogenic layer of periosteum forms cortical tissue; ii) then, parallel-fibred } \\
\text { lamellar bone is deposited on foetal woven bone cores as early as } 4-41 / 2 \text { months, as shown by } \\
\text { polarised-light microscopy; iii) it is not accurate to consider that human foetal cortical bone is } \\
\text { invariably all woven; late foetal and early post-natal bone is progressively replaced by lamellar } \\
\text { bone in primary osteons and, then, in secondary Haversian system osteons; iv) by } 2-3 \text { years } \\
\text { after birth (other than at periosteal surfaces) all cortical bone becomes lamellar, arranged into } \\
\text { dense Haversian systems. }\end{array}$ \\
\hline $\begin{array}{l}\text { Other vertebrate } \\
\text { species (including } \\
\text { many large mammals) }\end{array}$ & $\begin{array}{l}\text { In other vertebrate species i) woven bone is continually synthesised by the inner layer of the } \\
\text { periosteum pre- and postnatally and much of it persists until skeletal maturity; ii) woven bone } \\
\text { recurrent production and persistence in successive layers as fibrolamellar bone is a prominent } \\
\text { structural feature of the cortices; iii) fibrolamellar bone is structured in varying conformations } \\
\text { such as longitudinal, plexiform, reticular and radial along with some primary osteons; iv) } \\
\text { secondary osteons form in some species but rarely predominate. }\end{array}$ \\
\hline $\begin{array}{l}\text { Significant differences } \\
\text { between structure } \\
\text { of cortical bone in } \\
\text { humans and other } \\
\text { vertebrate species }\end{array}$ & $\begin{array}{l}\text { There are significant differences between the structure of cortical bone in humans and other } \\
\text { vertebrate species. Human bone, where almost the entire cortex has a predominantly secondary } \\
\text { osteonal (Haversian system) structure with no woven bone after the first few years of life, shows } \\
\text { considerable structural differences from most vertebrate species, including even some large } \\
\text { mammals, demonstrating persistence of woven bone on which lamellar bone is deposited in } \\
\text { plexiform and reticular patterns throughout the post-natal growth period. }\end{array}$ \\
\hline
\end{tabular}


Table 3a. Terminology for woven and lamellar collagen deposition in vertebrate cortical bone.

\begin{tabular}{|c|c|}
\hline $\begin{array}{l}\text { Classification of de } \\
\text { Ricqlès (1975) for } \\
\text { cortical bone tissue }\end{array}$ & $\begin{array}{l}\text { Primary bone tissue: i) fibrous (woven) bone - avascular or vascular fibrous bone; ii) lamellar-zonal } \\
\text { bone - avascular or vascular lamellar, periosteal lamellar with primary osteons; iii) fibrolamellar } \\
\text { complex bone - fibrous bone with primary osteons. } \\
\text { Secondary bone tissue: secondary osteons (Haversian systems) and non-Haversian lamellar bone } \\
\text { (further descriptions include lamellar or parallel-fibred non-vascular bone, lamellar or parallel- } \\
\text { fibred simple vascular bone, vascular canal surrounded by concentric bone lamellae or parallel- } \\
\text { fibred laminae = lamellar primary osteon). }\end{array}$ \\
\hline $\begin{array}{l}\text { Descriptive terms } \\
\text { for histology of } \\
\text { bone cortex }\end{array}$ & $\begin{array}{l}\text { A simpler terminology, increasingly found in many vertebrate studies, describes bone matrix } \\
\text { fibrillar pattern orientation as: i) fibrous or woven-fibred; ii) parallel-fibred, composed of an } \\
\text { orderly arrangement of closely packed fibres running parallel to one another; iii) lamellar, with } \\
\text { alternating spatial orientation of the fibres of successive layers. In lamellar bone, the predominant } \\
\text { fibre direction in the alternating layers is described as either an orthogonal (at right angles to one } \\
\text { another) or twisted plywood arrangement with differing rotations. }\end{array}$ \\
\hline $\begin{array}{l}\text { Fibrolamellar bone } \\
\text { or fibrolamellar } \\
\text { complex }\end{array}$ & $\begin{array}{l}\text { Fibrolamellar bone (fibrolamellar complex) forms the main structural unit of most cortical bones; } \\
\text { it is composed of woven bone (matrix tissue without orientation) originating from the periosteum } \\
\text { that forms a scaffold surrounded by primary osteons within lamellar or parallel-fibred bone. Thus, } \\
\text { the tissue complex has a mixed structure and often dense vascularisation where the woven fibrous } \\
\text { bone matrix combines with lamellar bone matrix forming intracortical primary osteons. Two } \\
\text { additional terms (referred to above in de Ricqlès system) describe primary bone tissue synthesis, } \\
\text { where the periodic growth layers show primary bone tissue disposed as i) lamellar-zonal bone, } \\
\text { where the zones are composed of lamellar or parallel-fibred bone matrix (generally in external } \\
\text { cortical layers); ii) fibrolamellar-zonal bone, where zones are composed of woven matrix with } \\
\text { abundant primary osteons that tend to compose the bulk of the innermost larger bones. }\end{array}$ \\
\hline Vessel orientation & $\begin{array}{l}\text { Vessel orientation directs patterns of surrounding matrix deposition. Vascular orientation of the } \\
\text { vessels and the pattern of bone formed can be longitudinal (vascular canals run parallel to the } \\
\text { long axis of the bone), radial (vascular canals radiate from the marrow and periosteum and extend } \\
\text { partially across the cortex, penetrating from the bone periphery at right angles to the long axis), } \\
\text { plexiform (vascular canals organised into a regular well defined plexus linking adjacent layers } \\
\text { with transverse bridges) and reticular (vascular canals disorganised, irregular and primarily } \\
\text { oblique) (Currey, 1960; Enlow, 1962). }\end{array}$ \\
\hline $\begin{array}{l}\text { Three-dimensional } \\
\text { structure of } \\
\text { fibrolamellar bone }\end{array}$ & $\begin{array}{l}\text { Much animal cortical bone is composed by repetitive layer synthesis of composites of woven and } \\
\text { lamellar bone (fibrolamellar), with the pattern dictated by the matrix relationship to the vasculature. } \\
\text { Four types are defined: laminar bone tissue, composed of fibrolamellar complexes of woven bone } \\
\text { with primary osteons with a circumferential orientation of vascular canals; plexiform bone tissue, } \\
\text { where the laminar bone has differing vascular orientations - longitudinal canals connected by } \\
\text { radial and circular canals; reticular bone tissue, with numerous primary osteons with oblique } \\
\text { vascular canals and overall irregular anastomoses; radial bone tissue, where the numerous primary } \\
\text { osteons are radially oriented. }\end{array}$ \\
\hline
\end{tabular}

\section{Table $3 b$. Proposed revisions to descriptive terminology for vertebrate cortical bone.}

\begin{tabular}{|l|l|}
\hline $\begin{array}{l}\text { Fibrolamellar to be } \\
\text { abandoned }\end{array}$ & $\begin{array}{l}\text { The woven bone component of cortical bone was far less extensive than previously thought. } \\
\text { Much of what had been considered woven bone appeared to be parallel-fibred ("non-lamellar") } \\
\text { arrayed in differing planes (from lamellar bone) as determined by polarised-light microscopy } \\
\text { and multiplanar sectioning. Fast growing, highly vascularised composite bone tissue of woven } \\
\text { bone and lamellar bone was referred to as laminar to plexiform primary bone (based on vascular } \\
\text { organisation). }\end{array}$ \\
\hline HOPB proposed & $\begin{array}{l}\text { This term was proposed to define combined lamellar tissue (with primary osteons) and parallel- } \\
\text { fibred tissue (referred to as non-lamellar). HOPB refers to bone in terms of its development, } \\
\text { with woven bone produced by static osteoblasts (mesenchymal osteoblasts) and lamellar/ } \\
\text { parallel-fibred bone by dynamic osteoblasts (surface osteoblasts) (Stein and Prondvai, 2014). }\end{array}$ \\
\hline $\begin{array}{l}\text { Fibrolamellar } \\
\text { complex term } \\
\text { maintained } \\
\text { (restricted role); new } \\
\text { term, woven-parallel } \\
\text { complex, added }\end{array}$ & $\begin{array}{l}\text { The term fibrolamellar complex has been maintained (in a restricted role) and a new term, } \\
\text { woven-parallel complex, added to incorporate early development. Thus, the term woven-parallel } \\
\text { complex describes a broad range of bone-forming tissue and the term fibrolamellar complex } \\
\text { is maintained as a subset of woven-parallel complex describing densely vascularised primary } \\
\text { periosteal tissues (cortical bone) where woven/fibrous bone forms between the vascular canals } \\
\text { and is then surrounded by lamellar or parallel-fibred bone (HOPB appeared to be useful to } \\
\text { explain findings rather than serving as a separate classification term) (Prondvai } e t \text { al., 2014). }\end{array}$ \\
\hline $\begin{array}{l}\text { Correlation of } \\
\text { concepts }\end{array}$ & $\begin{array}{l}\text { The woven scaffold represents the fibrous component derived from static/mesenchymal } \\
\text { osteoblasts and the lamellar component refers to both lamellar and non-lamellar (parallel-fibred) } \\
\text { bone derived from dynamic/surface osteoblasts. }\end{array}$ \\
\hline
\end{tabular}


Table 4. Structural characteristics of woven and lamellar bone.

\begin{tabular}{|c|c|}
\hline Matrix conformation & $\begin{array}{l}\text { Woven bone has randomly arrayed collagen fibres; lamellar bone has fibres aligned in } \\
\text { a parallel array. }\end{array}$ \\
\hline Polarised light transmission & $\begin{array}{l}\text { Woven bone is isotropic when examined by polarised-light microscopy, not transmitting } \\
\text { light regardless of the plane of observation; lamellar bone is anisotropic, transmitting light } \\
\text { that is parallel to the two parallel polarisers, due to the bone fibres being in a parallel array. }\end{array}$ \\
\hline $\begin{array}{l}\text { Osteoblast/osteocyte cell } \\
\text { shape, number and position }\end{array}$ & $\begin{array}{l}\text { Woven bone osteoblasts are round to oval, present in larger numbers (than cells of lamellar } \\
\text { bone) per unit area and embedded within the collagenous matrix that surrounds them in } \\
\text { a } 360^{\circ} \text { arc. Lamellar bone osteoblasts are aligned on the surface of woven bone, deposit } \\
\text { bone only on the surface they cover, touch one another and communicate through gap } \\
\text { junctions and, generally, are only one cell-layer thick. Lamellar bone osteocytes are } \\
\text { elongated and elliptical in shape, less numerous per unit area than woven osteoblasts } \\
\text { and have their long axes parallel to the lamellae. Woven bone cells are referred to as } \\
\text { osteoblasts when surrounded by a randomly oriented loosely packed collagen matrix } \\
\text { since they continue to synthesise matrix; they become woven bone osteocytes when the } \\
\text { woven bone is encased by lamellar bone. }\end{array}$ \\
\hline $\begin{array}{l}\text { Orientation of the lacunar- } \\
\text { canalicular system }\end{array}$ & $\begin{array}{l}\text { Woven bone osteoblasts/osteocytes are present randomly in round to oval lacunae, } \\
\text { irregularly positioned throughout the woven bone and their canaliculi radiate in all } \\
\text { directions from the cell surface circumferentially to course through the matrix in irregular } \\
\text { pathways. Lamellar bone osteocytes are present in elliptical elongated lacunae that run } \\
\text { parallel to the lamellae and their cell processes lie in canaliculi perpendicular to the walls } \\
\text { of the lacunae. }\end{array}$ \\
\hline $\begin{array}{l}\text { Density and orientation of } \\
\text { bone vascularity }\end{array}$ & $\begin{array}{l}\text { Woven bone formation occurs in close relationship to vascularity but with no specific } \\
\text { pattern. Lamellar bone formation also occurs in specific relationship to vascularity but } \\
\text { Haversian system bone (osteons) forms circumferentially around longitudinal intracortical } \\
\text { vessels as surface osteoblasts deposit lamellar bone progressively closing in on the vessel. } \\
\text { Other vessel patterns are transverse (radial) in humans through Volkmann's canals and } \\
\text { oblique in other species, as plexiform or reticular bone. }\end{array}$ \\
\hline $\begin{array}{l}\text { Rate and position of matrix } \\
\text { synthesis }\end{array}$ & $\begin{array}{l}\text { Woven bone is synthesised rapidly and de novo at sites where no bone tissue is present; } \\
\text { lamellar bone is synthesised in a slower fashion and only on a pre-existing scaffold (of } \\
\text { woven bone, lamellar bone or calcified cartilage). }\end{array}$ \\
\hline
\end{tabular}

lamellar patterns based on the authors' observations and investigations, a detailed literature review on matrix conformation in varying circumstances and palaeohistological studies documenting woven and lamellar bone structure in many vertebrate species.

\section{Materials and Methods}

\section{Tissues examined}

Normal bone, diaphyseal and metaphyseal femur and tibia from i) embryonic and postnatal mouse, rabbit and pig and ii) foetal, new-born, childhood and adult human.

Repair bone from i) skeletally mature rabbit, $2.4 \mathrm{~mm}$ diameter full-thickness cortical diaphyseal defects (Shapiro, 1988); ii) chicken, oval $10 \times 3 \mathrm{~mm}$ full-thickness cortical diaphyseal defects (Glimcher et al., 1980); iii) rabbit fractured-femur endochondral bone repair with external callus (Shapiro, 2008; Shapiro, 2016); iv) distraction osteogenesis rabbit tibial lengthening procedure (Shapiro, 2016; Shapiro et al., 1992); v) full-thickness articular cartilage defects into subchondral bone in skeletally mature rabbit distal femur (Shapiro et al., 1993); vi) transphyseal defects in skeletally immature rabbit proximal tibia (Jaramillo et al., 1990); vii) piglet femoral head osteonecrosis secondary to ischemia (avascular necrosis) induced by intracapsular circumferential ligatures around femoral neck base (Shapiro et al., 2009).

Pathological human bone from osteogenesis imperfecta (femoral and tibial bone from 30 patients with lethal perinatal, progressively deforming and autosomal dominant variants) [Maguire et al. (2011) Osteogenesis imperfecta bone: correlation of histologic structure and radiographic appearance. American Academy of Orthopaedic Surgeons annual meeting, San Diego, CA, USA; Shapiro, 2016; Shapiro and Flynn (2005) Variable structure of osteogenesis imperfecta bone. J Bone Miner Res 20 Suppl 1: S175; Van Dijk and Sillence, 2014] and osteosarcoma (distal femoral and proximal tibial metaphyseal tissue from 10 adolescent patients) (Shapiro, 1983; Shapiro and Eyre, 1982).

Light microscopy and polarised-light microscopy Tissues were decalcified in $10 \%$ formic acid and processed for light-microscope examination using either paraffin-wax-embedding (sections stained with haematoxylin and eosin or safranin O-fast green) or plastic-embedding (JB4 plastic, Polysciences, Warrington, PA, USA) (sections stained with $1 \%$ toluidine blue). Light microscopy examination was performed using an Olympus BX50 microscope with digital camera. Tissue sections were examined by polarised-light microscopy (Olympus BX50 microscope). Matrix polarisation was documented 
Table 5a. Terminology for osteoblast synthesis of woven and lamellar bone.

\begin{tabular}{|c|c|}
\hline $\begin{array}{l}\text { Osteoblast } \\
\text { terminology }\end{array}$ & $\begin{array}{l}\text { hapiro }(1988,2008) \text { : MOBLs synthesise woven bone; SOBLs synthesise lamellar bone. } \\
\text { erretti et al., (2002); Marotti (2010): static osteogenesis leads to woven bone formation; dynamic } \\
\text { teogenesis to lamellar bone formation. }\end{array}$ \\
\hline $\begin{array}{l}\text { Early } \\
\text { observation } \\
\text { of the } \\
\text { phenomenon }\end{array}$ & $\begin{array}{l}\text { Knaggs (1925) recognised that intramembranous bone formation involves two different cell } \\
\text { populations. Discussing pathological bone formation in osteitis deformans (Paget's Disease), Knaggs } \\
\text { observed that, once original bone disappear, there is "the substitution of a vascular connective tissue } \\
\text { (osteogenic tissue) in place of it and its intertrabecular marrow and the formation of new bone from } \\
\text { this connective tissue, in the first instance always by metaplasia...... The term 'metaplasia' is used } \\
\text { here to distinguish bone formation direct from the connective tissue from that which is associated } \\
\text { with rows of osteoblasts." }\end{array}$ \\
\hline $\begin{array}{l}\text { Derivation } \\
\text { of the terms } \\
\text { MOBL and } \\
\text { SOBL }\end{array}$ & $\begin{array}{l}\text { While all osteoblasts are mesenchymal in lineage, the term MOBL was chosen to indicate initial or } \\
\text { de novo bone formation within a cellular mass (woven bone) where no bone previously existed, as } \\
\text { would occur in the mesenchyme of classical embryological terminology. The osteoblast of lamellar } \\
\text { bone is referred to as SOBL since it aligns in a linear array on the surface of woven bone (or adjacent } \\
\text { lamellar bone) to synthesise parallel-fibred lamellar bone. }\end{array}$ \\
\hline $\begin{array}{l}\text { aic } \\
\text { is }\end{array}$ & $\begin{array}{l}\text { The term static refers to synthesis of woven bone (static osteogenesis) occurring by differentiating } \\
\text { cells that surround themselves with a matrix at a place where they are already present (hence static). } \\
\text { The term dynamic is used to imply movement of the cells to position themselves along bone surfaces } \\
\text { where they synthesise lamellar bone (dynamic osteogenesis). }\end{array}$ \\
\hline & $\begin{array}{l}\text { Maximow (1927) recognised and defined the mesenchymal cell as a precursor cell to connective and } \\
\text { haematopoietic tissues and referred to it as a stem cell. Weiss and Garber (1952) defined the changing } \\
\text { shapes of the mesenchymal cell in development. Kfoury and Scadden (2015) outlined molecular } \\
\text { components of its contributions to forming connective and haematopoietic tissue. }\end{array}$ \\
\hline $\begin{array}{l}\text { Value of } \\
\text { mesenchymal/ } \\
\text { surface } \\
\text { terminology }\end{array}$ & $\begin{array}{l}\text { Mesenchymal and surface are descriptive positional terms referring to osteoblasts. The first defines } \\
\text { an osteoblast emerging from an undifferentiated mesenchymal tissue mass; the second, an osteoblast } \\
\text { positioned in a linear array on a surface scaffold. Both define active processes requiring cell migration, } \\
\text { movement and differentiation from the mesenchymal tissue mass at different times and positions. } \\
\text { Bone formation de novo in the woven conformation (mesenchymal osteoblasts) is active and rapid; } \\
\text { lamellar bone formation (surface osteoblasts) is a slower orderly process on the scaffold. } \\
\text { The terms static and dynamic imply levels of activity that do not accurately reflect actual cell } \\
\text { functions. The term static is inaccurate since these cells actively migrate to and differentiate at their } \\
\text { functional sites and demonstrate strong synthetic force making bone de novo. Those cells are extremely } \\
\text { active, forming bone faster, in a more dynamic fashion, than the slower and better oriented actions of } \\
\text { the surface osteoblasts. Once a woven bone scaffold forms, cells already present switch to unidirectional } \\
\text { surface synthesis from multidirectional pericellular synthesis. }\end{array}$ \\
\hline
\end{tabular}

Table 5b. Description of cells in woven and lamellar bone.

\begin{tabular}{|l|l|}
\hline Lamellar bone & $\begin{array}{l}\text { There is a clear distinction between lamellar bone osteoblasts and osteocytes. Osteoblasts are cells that } \\
\text { are actively synthesising bone matrix. Osteoblasts synthesising lamellar bone are aligned in a linear } \\
\text { array (often only one cell in depth), lie on a firm scaffold surface, deposit collagen in a unidirectional } \\
\text { fashion, extruding it only from that part of the cell lying against the scaffold surface, and deposit } \\
\text { collagen matrix with the fibres in a parallel array. These cells are referred to as SOBLs. Osteocytes } \\
\text { are living bone cells no longer actively synthesising bone and surrounded by a mineralised matrix. } \\
\text { Osteocytes of lamellar bone are elongated elliptical-shaped cells, have long axes that are parallel to } \\
\text { the lamellae within which they lie and are embedded in a matrix that mineralises with lamellation. }\end{array}$ \\
\hline Woven bone & $\begin{array}{l}\text { The distinction between woven bone osteoblasts and osteocytes is not as clear as for lamellar bone. } \\
\text { Osteoblasts are cells that are actively synthesising bone matrix. Osteoblasts synthesising woven } \\
\text { bone are randomly positioned, lie within mesenchymal tissue, are round to oval, are densely packed } \\
\text { initially with little surrounding matrix, deposit collagen in a 360 radius and become embedded in } \\
\text { progressively increasing amounts of matrix whose collagen fibres are in random (woven) array. These } \\
\text { cells are referred to as MOBLs. }\end{array}$ \\
\hline $\begin{array}{l}\text { When MOBLs } \\
\text { can be } \\
\text { considered as } \\
\text { mesenchymal } \\
\text { osteocytes }\end{array}$ & $\begin{array}{l}\text { The structural identification of cells as MOBLs is more prolonged and not as rigidly defined as } \\
\text { for SOBLs. This is because MOBLs are actively synthesising bone matrix (the defining term for an } \\
\text { osteoblast) and depositing it circumferentially around the cell over a time from when there is very little } \\
\text { matrix surrounding the cell until there is a relatively large amount of matrix surrounding it. There are } \\
\text { woven bone osteocytes but (unlike in lamellar bone) a cell surrounded by matrix cannot serve as the } \\
\text { definition of a woven bone osteocyte since it is still synthesizing tissue. MOBLs can be considered as } \\
\text { no longer actively synthesising woven bone when the woven bone accumulation is lined by SOBLs } \\
\text { and lamellar bone. Then, the woven bone cells are referred to as woven bone osteocytes. }\end{array}$ \\
\hline
\end{tabular}


with a light microscopy photomicrograph followed by a polarised-light microscopy view of the same section in the same orientation.

\section{Light microscopy histomorphometry}

Cell area/total area ratios in woven and lamellar bone Histomorphometry quantified the cell area/total area ratios of woven and lamellar bone. This ratio served as a cell/matrix assessment reflecting the relative amount of matrix synthesised by a cell per unit area. Quantitation was performed on normal human bone from foetal, neonatal, childhood and adult specimens and on osteogenesis imperfecta bone from three main variants (lethal perinatal, progressive-deforming and autosomal dominant). Cells and types of matrix associated were outlined and cell area/total area ratios determined using the Zeiss Interactive Digital Analysis System (Zidas).

Length/width osteocyte and osteoblast ratios in woven and lamellar bone

The ratio of length to width was measured in lamellar bone osteocytes and woven bone osteoblasts/ osteocytes in normal rabbit cortical bone and in rabbit repair bone from $2.4 \mathrm{~mm}$ cortical diaphyseal defects (Shapiro, 1988).

\section{Transmission electron microscopy (TEM)}

Tissues examined by TEM included new-born mouse femoral cortical bone and femoral and tibial bone from adolescent patients with osteogenesis imperfecta undergoing osteotomy. Cortical bone was processed by immediate sectioning into small fragments of approximately $1 \times 1 \times 1 \mathrm{~mm}$ on a cold glass surface (over ice) with tissues bathed with droplets of $1 \%$ glutaraldehyde. The tissues were fixed using two parts osmium tetroxide to one part glutaraldehyde in $0.1 \mathrm{M}$ cacodylate buffer at $0{ }^{\circ} \mathrm{C}$ for $3 \mathrm{~h}$. Following fixation, bone was decalcified with $7.5 \%$ ethylenediaminetetraacetic acid (EDTA) (pH 8.3 ) in $2.5 \%$ glutaraldehyde for $24 \mathrm{~h}$ when it was soft. The tissues were postfixed for $3 \mathrm{~h}$ in $1 \%$ osmium tetroxide in $0.1 \mathrm{M}$ cacodylate buffer, dehydrated in increasing concentrations of alcohol, then placed in a $1: 1$ propylene oxide-Epon mixture for 1 week. Tissues were embedded in EPON 812 resin (3A:7B) (E.F. Fullam, Inc, Latham NY, USA), sectioned at $1 \mu \mathrm{m}$ thickness, stained with $1 \%$ toluidine blue for light microscopy examination and, then, trimmed and sectioned at $60 \mathrm{~nm}$ thickness (Ultrotome III, LKB Instruments, Stockholm, Sweden) for TEM examination after staining with $3 \%$ lead citrate ( $30 \mathrm{~min}$ ) and $0.5 \%$ uranyl acetate ( $30 \mathrm{~min})$. Sections were examined on a JEOL1200 TEM (JEOL, Tokyo, Japan and JEOL USA, Peabody, MA, USA) at $60-80 \mathrm{kV}$ and on an FEI Tecnai F20 TEM (Thermo Fisher Scientific) at $200 \mathrm{kV}$ at Stanford Nano Shared Facilities, Palo Alto, CA, USA. Film (Eastman Kodak, Rochester, NY, USA and Fuji Photo Film) and digital (Olympus BX50 microscope) photography were used.
All animal and human tissue studies were performed after obtaining permissions from the appropriate committees and hospitals.

\section{Results}

\section{Normal bone development}

MOBLs synthesising woven bone and SOBLs synthesising lamellar bone

MOBLs synthesising woven bone and SOBLs synthesising lamellar bone on the woven bone scaffold are illustrated (Fig. 1,2). This terminology refers to normal, repair and pathological bone formation throughout all vertebrates. It encompasses initial woven and subsequent lamellar (parallelfibred) bone formation leading to both eventual osteonal and fibrolamellar cortical tissue.

Woven bone formation closely followed by lamellar bone formation in normal development

Normal long bone formation in vertebrates followed a consistent pattern combining both intramembranous and endochondral mechanisms. Cortices were formed by the intramembranous mechanism mediated by the inner cambial layer of the periosteum, while metaphyseal and marrow trabeculae were formed by the endochondral mechanism mediated by the epiphyseal growth plates (physes), with bone deposited internally on a scaffold of calcified cartilage (Rivas and Shapiro, 2002). These two mechanisms also characterised axial bone development (vertebrae, ribs, pelvis).

Cortical and trabecular bone development: mouse, rabbit, pig; embryonic, postnatal

In the developing embryonic long bone, woven bone was formed initially by MOBLs of the inner (cambial) layer of the periosteum at the primary centre of ossification surrounding the mid-portion of each cartilage model. This represented the intramembranous mechanism of bone formation. Then, synthesis of lamellar bone occurred by SOBLs once a region of woven bone was sufficiently large to serve as a scaffold. Lamellar bone was invariably deposited on collections of woven bone synthesised by the periosteum. Then, woven bone synthesis passed towards both ends of the long bone eventually surrounding the developing physis and becoming a component of the perichondrial ossification groove of Ranvier. The bone surrounding the physis, referred to as the bony bark of Lacroix, was initially woven in conformation (like the rest of the cortex). At the deepest part of the groove, the inner (cambial) layer of the periosteum is continuous, with a dense cellular accumulation, a collection of pre-osteoblasts that are in the process of becoming MOBLs (Shapiro et al., 1977). Then, woven bone formed in the depths of the groove and the outer part of the inner periosteal layer while the inner part 
of the periosteal layer was composed increasingly of lamellar bone synthesised by SOBLs on initially woven collections. Photomicrographs from the inner cambial layer of a new-born rabbit femur and the groove region of a foetal piglet (Fig.1,2) demonstrated the sequence of bone formation from pre-osteoblast to woven bone to early lamellar bone. Bone formed through the endochondral mechanism was deposited internally at the metaphysis on calcified cartilage cores extending from the physis (Fig. 3a-c). During periods of extremely rapid growth, woven bone was deposited on the cartilage cores initially and, then, quickly covered by lamellar bone (Fig. 3c). Much of the bone was synthesised directly on the calcified cartilage and was parallel-fibred (lamellar) since the cores served as scaffold for the SOBLs (Fig. $3 \mathbf{a}, \mathbf{b})$. Both woven bone and cartilage cores were resorbed by osteoclasts once their scaffold function was completed (Fig. 3b,d). Photomicrographs of lamellar on woven bone synthesis in pigs were similar

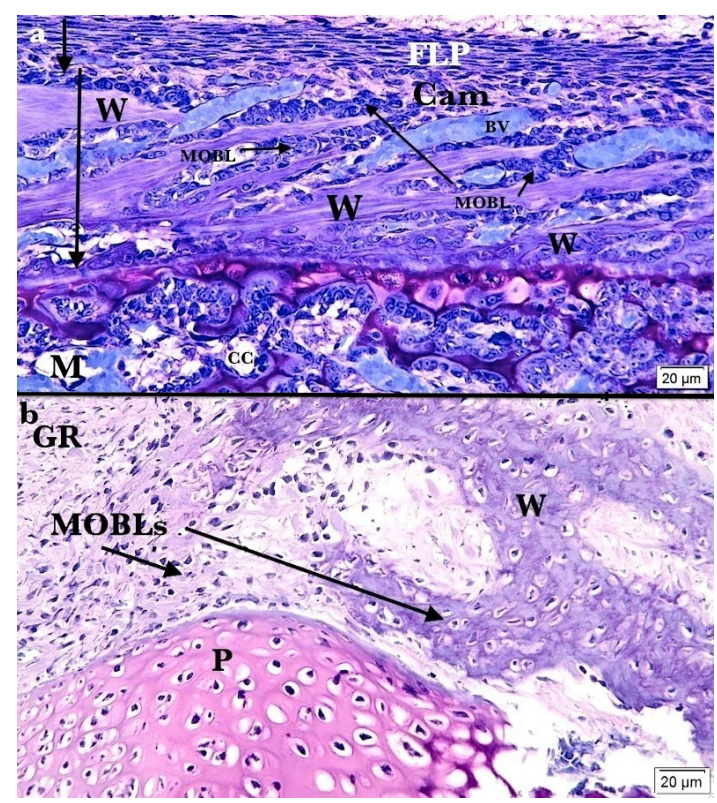

Fig. 1. Photomicrographs show regions of developing bone, periosteum and groove of Ranvier, where woven bone was prominent. (a) Photomicrograph shows a region of late embryonic rabbit femoral periosteum, cortex and adjacent metaphysis sectioned along the longitudinal axis. Short arrow at upper left corner outlines outer fibrous layer of periosteum; longer arrow below outlines inner cambial layer of periosteum and woven bone of cortex. $\mathrm{W}=$ woven bone; $\mathrm{M}=$ metaphysis; $\mathrm{BV}=$ blood vessel; $C C=$ calcified cartilage within metaphysis; $\mathrm{FLP}=$ fibrous layer of periosteum; Cam $=$ cambial layer of periosteum. Plastic-embedded section stained with $1 \%$ toluidine blue. (b) Photomicrograph shows periphery of the physis $(\mathrm{P})$ and adjacent perichondrial ossification groove of Ranvier (GR) in foetal piglet distal femur. On the right, woven bone (W) synthesis occurred at the depths of groove from MOBLs. This represents the furthest extension of periosteal intramembranous cortical bone formation. Plasticembedded section stained with $1 \%$ toluidine blue.

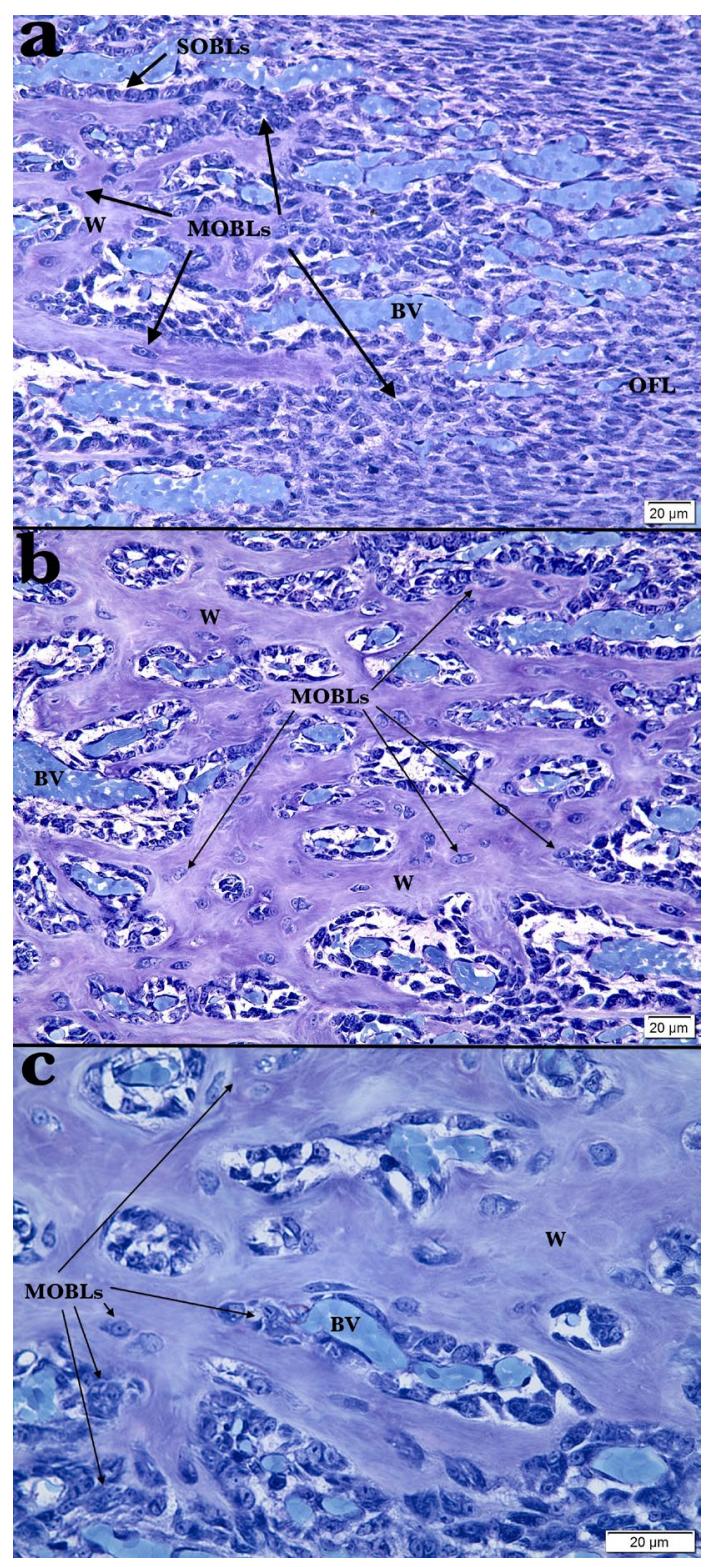

Fig. 2. Photomicrographs show developmental sequence in embryonic periosteum as MOBLs synthesised woven bone. (a) Oblique section through late embryonic rabbit femoral periosteum highlighted cambial layer with woven bone formation. $\mathrm{OFL}=$ outer fibrous layer (of periosteum); $\mathrm{W}=$ woven bone; $\mathrm{BV}=$ blood vessel (vessels are concentrated in the outer part of the inner cambial layer). SOBLs quickly forming on newly synthesised woven bone scaffolds. Plastic-embedded section stained with $1 \%$ toluidine blue. (b) Oblique section through late embryonic rabbit femoral periosteum highlighted woven bone synthesis. Plastic-embedded section stained with $1 \%$ toluidine blue. (c) Higher power photomicrograph of an oblique section through late embryonic rabbit femoral periosteum showed woven bone formation from mesenchymal osteoblasts throughout the section. Note close relationship of blood vessels with mesenchymal osteoblasts. Plastic-embedded section stained with $1 \%$ toluidine blue. 
throughout embryonic development and at 10 weeks post-natal (Fig. 4a-d, 5a,b). Piglet cortical bone was fibrolamellar, formed with repetitive layer-by-layer synthesis, with the woven bone scaffold maintained. The bone was reticular and plexiform rather than exclusively osteonal as in humans. Some primary osteons formed, but the repetitive fibrolamellar pattern was synthesised until skeletal maturation.

Human cortical and trabecular bone development (foetal, post-natal)

In 4-4 $1 / 2$ month-old foetal long bones there was already extensive parallel-fibred lamellar bone deposited on woven bone initially synthesised by the periosteum and on calcified cartilage at the metaphyses (Fig. 5c, 6a-d). Examination by polarisedlight microscopy highlighted this observation. By the new-born period, lamellar bone predominated over woven bone in the cortices. The pattern became exclusively lamellar in childhood, characterised by densely packed Haversian systems with interstitial lamellar bone interposed and no woven bone.

\section{Repair bone models and mechanisms}

Bone repaired itself by differing mechanisms (endochondral or intramembranous) depending on the environment provided, such as length of gaps, stability between fragments and repair site vascularity.

Intramembranous bone repair in a stable mechanical environment; circular/cylindrical $2.4 \mathrm{~mm}$ cortical defect in rabbit femur diaphyses

As soon as a drilling defect through one cortex of the diaphysis of a young rabbit femur was done, blood filled the space and fibrinous arcades formed within the blood clot across the defect from wall to wall (Shapiro, 1988). Undifferentiated mesenchymal cells (narrow, elongated) lay parallel to the fibrinous arcade, in conjunction with vascularisation. They gradually assumed an oval to round shape as differentiation proceeded along the pre-osteoblast to MOBL line. The progressive developmental sequence from undifferentiated mesenchymal cells (Fig. 7a) to MOBLs, with increasing woven tissue synthesis (Fig. $7 \mathbf{b})$, to SOBLs, synthesising lamellar on woven bone (Fig. 7c), was demonstrated. At 1 week, new bone formation beginning in the marrow advanced to the periphery of the defect (Fig. 7d).

Repair did not occur uniformly with the same tissue pattern across the entire defect. Initial new bone synthesis occurred peripherally apposed to the rim of

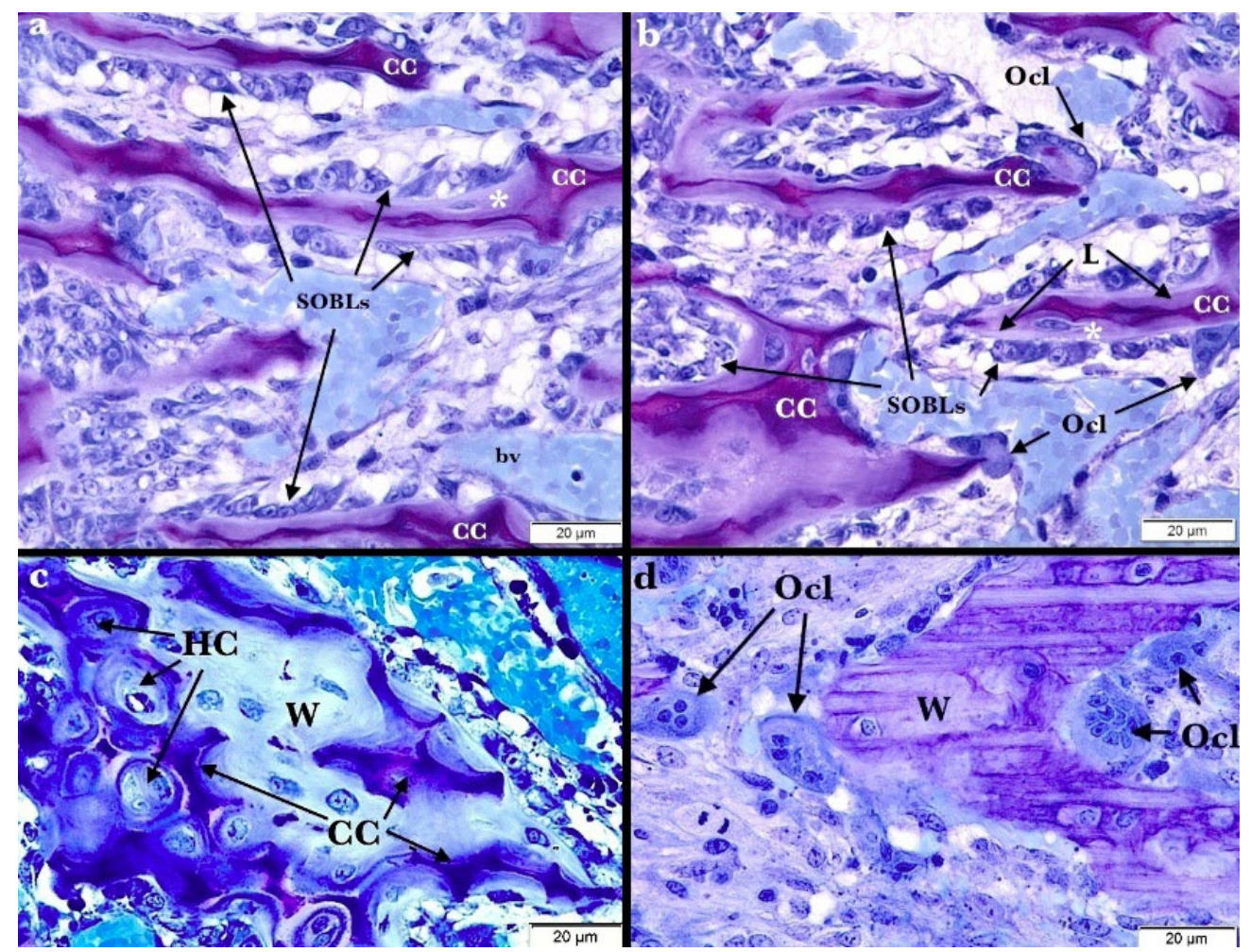

Fig. 3. Photomicrographs show examples of SOBLs synthesising lamellar bone on rigid calcified cartilage cores in metaphysis, woven bone synthesis adjacent to hypertrophic chondrocytes in metaphysis and osteoclasts resorbing woven bone. $(\mathbf{a}, \mathbf{b})$ In the metaphysis, lamellar bone was deposited directly onto the cartilage cores, which served as scaffolds. $\mathrm{L}=$ lamellar bone; ${ }^{*}=$ lamellar bone with characteristic elongated osteocytes; $\mathrm{CC}$ = calcified cartilage cores; $\mathrm{Ocl}=$ osteoclasts; $\mathrm{bv}=$ blood vessel. $(\mathbf{c})$ Woven bone (W) formation occurred immediately adjacent to lower physeal hypertrophic chondrocytes (HC) on and between calcified cartilage cores (CC). (d) Woven bone (W) at distraction osteogenesis site was undergoing resorption by multinucleated osteoclasts (Ocl). (a-c) From neonatal mouse distal femoral metaphysis. (d) From site of distraction osteogenesis. 
lamellar cortical bone, with the central defect region healing last. The initial deposits on the cortex were woven but occasionally the persisting cortex serving as a scaffold allowed for a thin incomplete rim of direct lamellar bone synthesis. Examining an entire repair field from cortex to cortex at 2 weeks, adjacent to the periphery, woven matrix (initially synthesised) had become covered by a single-cell layer of SOBLs that, then, synthesised parallel-fibred lamellae (Fig. 7e). Advancing towards the centre, mesenchymal cells had differentiated into MOBLs surrounding themselves with a woven bone matrix. The central part of the defect was filled with undifferentiated mesenchymal cells. By 4 weeks, repair bone had filled the defect. Accumulations of woven bone were rimmed completely by SOBLs and lamellar bone and resorption of woven-bone segments by osteoclasts were underway. The proportion of lamellar bone increased quickly and, eventually, no woven bone persisted. The lamellar repair bone had become organised into Haversian system osteons. Polarisedlight microscopy showed lamellar repair but with fibril plane orientation perpendicular to the long axis of the persisting cortex even several weeks after injury.

Intramembranous bone repair in a stable mechanical environment; oval cortical defect $10 \times 3 \mathrm{~mm}$ in chicken humerus An oval cortical defect in the chicken also allowed for bone formation in a stable environment by the intramembranous mechanism, eliminating the need for healing through endochondral repair (Glimcher et al., 1980). Bone tissue deposition was initiated against the rim of persisting cortical bone and, then, passed inwards towards the centre of the defect. The 4-week specimen was informative regarding matrix deposition. Bone at the periphery was already composed of osteonal lamellar bone synthesised on the initial woven bone deposits. Closer to the centre of the defect, woven bone predominated, with some SOBLs seen, while, in the centre of the defect, undifferentiated mesenchymal cells were differentiating into MOBLs and beginning to synthesise woven bone (Fig. 8a,b).

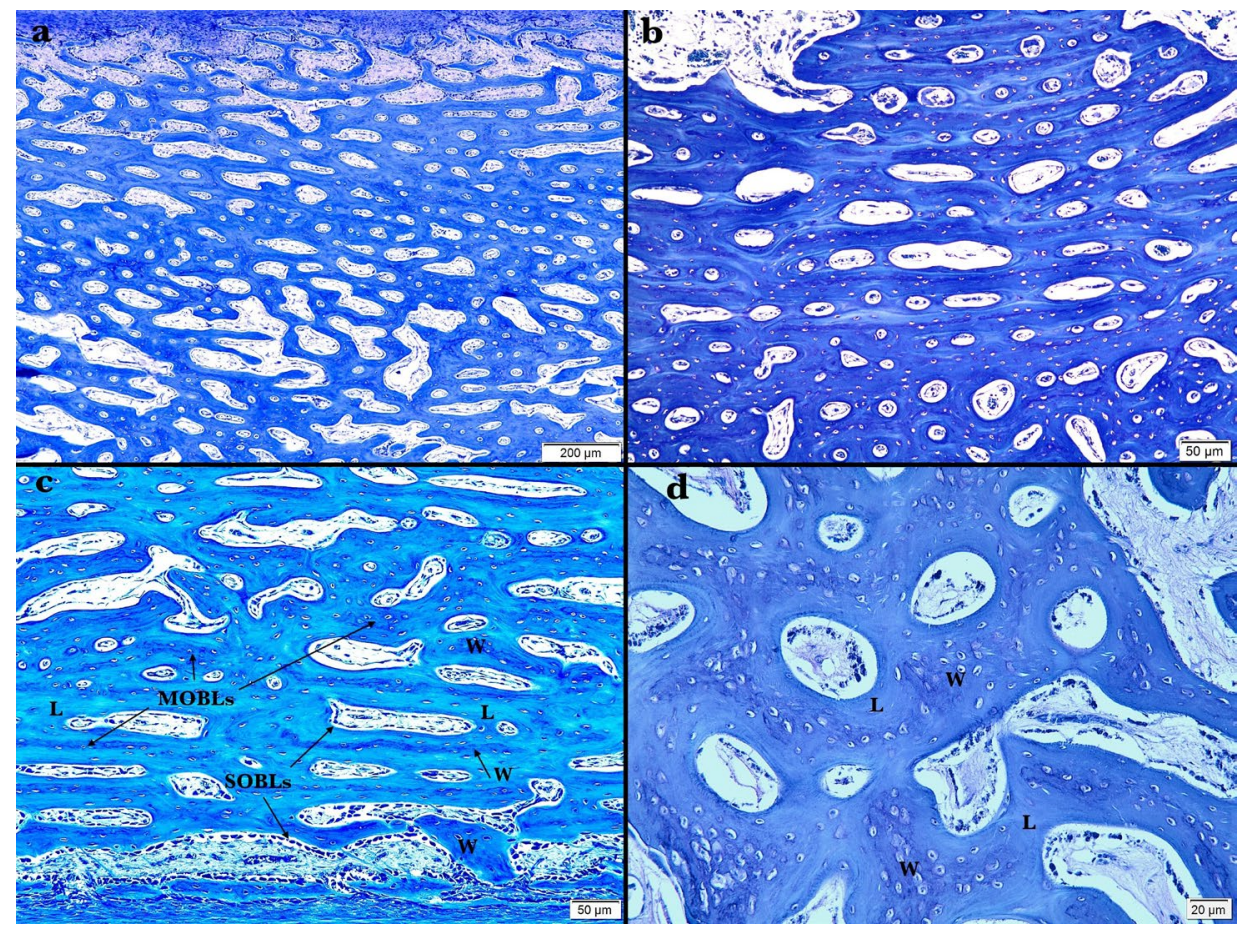

Fig. 4. Photomicrographs show late stage foetal piglet femoral cortices sectioned in the longitudinal plane. (a-d) All sections were plastic-embedded and stained with $1 \%$ toluidine blue. (a) Cortical bone showed a characteristic fibrolamellar pattern. The outer fibrous layer of periosteum is on the top, with a thin layer of woven bone immediately below it; most of the cortical tissue is fibrolamellar in plexiform arrangement. (b) Parallel-fibred lamellar bone appear lighter blue while central cores of woven/fibrous tissue are darker blue. (c) Periosteum is at the bottom of the image. Fibrolamellar bone is seen; the use of partially-polarised illumination shows lamellar bone (L) to be lighter blue and woven bone (W) darker blue. Partially-polarised illumination for microscopy highlighted the woven and lamellar matrix components while still allowing the cellularity to be seen. The woven regions were more cellular than the lamellar regions. The cells within the lamellae were flattened (elliptical) and parallel to the long axis of the lamella. Woven bone formation predominated at the periosteum (at bottom) but SOBLs were deposited on the woven cores once formed. (d) Late stage foetal piglet femoral cortex is shown in cross-section. The fibrolamellar cortical bone was forming, with central cores of initially synthesised woven bone (W) surrounded by parallel fibred lamellar bone (L) synthesised on the woven cores. The lamellar regions were organising into primary osteons. 
Endochondral bone repair in an unstable mechanical environment; rabbit femur

Fractured rabbit femora treated with lower extremity casts providing only partial bone fragment immobilisation led to healing by the endochondral/ external bone callus repair mechanism (Shapiro, 2008; Shapiro, 2016). Once a stabilising cartilage callus formed at the fracture site, there was gradual vascularisation of the cartilaginous tissue mass leading to woven bone formation on calcified cartilage followed by deposition of lamellar bone on the initial woven collections (Fig. 8c,d). Periosteum distant from the fracture site synthesised intramembranous bone directly in the woven to lamellar sequence.

Intramembranous bone repair in a stable mechanical environment with controlled longitudinal distraction; rabbit tibia

Distraction osteogenesis enabled for simultaneous bone formation and lengthening without an intermediate cartilage phase. Stability was provided by external fixation and longitudinal distraction separated the fragments (Shapiro et al., 1992; Shapiro, 2016). Following application of a tibial distraction device and complete osteotomy, bleeding at the site and formation of a fibrinous clot occurred. Blood vessel and undifferentiated mesenchymal cell invasion followed. Mesenchymal cells, initially thin and elongated, became oval to round as differentiation progressed along the osteoblast line. Repair was not uniform along the distraction gap. It began with woven bone synthesis adjacent to the cut cortices and occurred last at the central gap region. As gradual lengthening occurred, a range of regenerate bone was seen histologically. MOBLs and woven bone deposition were aligned longitudinally along the long axis by mechanical distraction. Shortly after woven bone synthesis, SOBLs aligned preferentially on the surface and synthesised lamellar bone. At 2 weeks, the woven repair bone adjacent to the cut cortices was surrounded completely by lamellar bone. Towards the centre of the gap, woven bone was relatively more abundant as compared to lamellar bone while, centrally, a few undifferentiated mesenchymal cells were present. As lengthening and osteogenesis proceeded, woven bone became completely covered by lamellar bone and, then, resorbed by osteoclasts (Fig. 9a-e).

Other experimental models showing invariable synthesis of woven bone repair followed by lamellar bone deposition are summarised in Table 6.

\section{Bone formation in pathological disorders \\ Osteogenesis imperfecta}

Histological assessments on multiple bone samples from 30 patients with osteogenesis imperfecta revealed the progression of woven to lamellar bone formation in the varying types (Fig. 10a, b; 11a-d). In the most severe lethal perinatal variants (Sillence II), woven bone only in small amounts was synthesised; in less severe progressively deforming variants (Sillence III, IV), lamellar bone was synthesised on woven cores; while in the mildest benign autosomal dominant form (Sillence I), lamellar bone predominated in varying patterns [Maguire et al. (2011) Osteogenesis imperfecta bone: correlation of histologic structure and radiographic appearance. American Academy of Orthopaedic Surgeons annual meeting, San Diego, CA, USA; Shapiro, 1985; Shapiro, 2016; Shapiro and Flynn (2005) Variable structure of osteogenesis imperfecta bone. J Bone Miner Res 20 Suppl 1: S175; Van Dijk and Sillence, 2014].

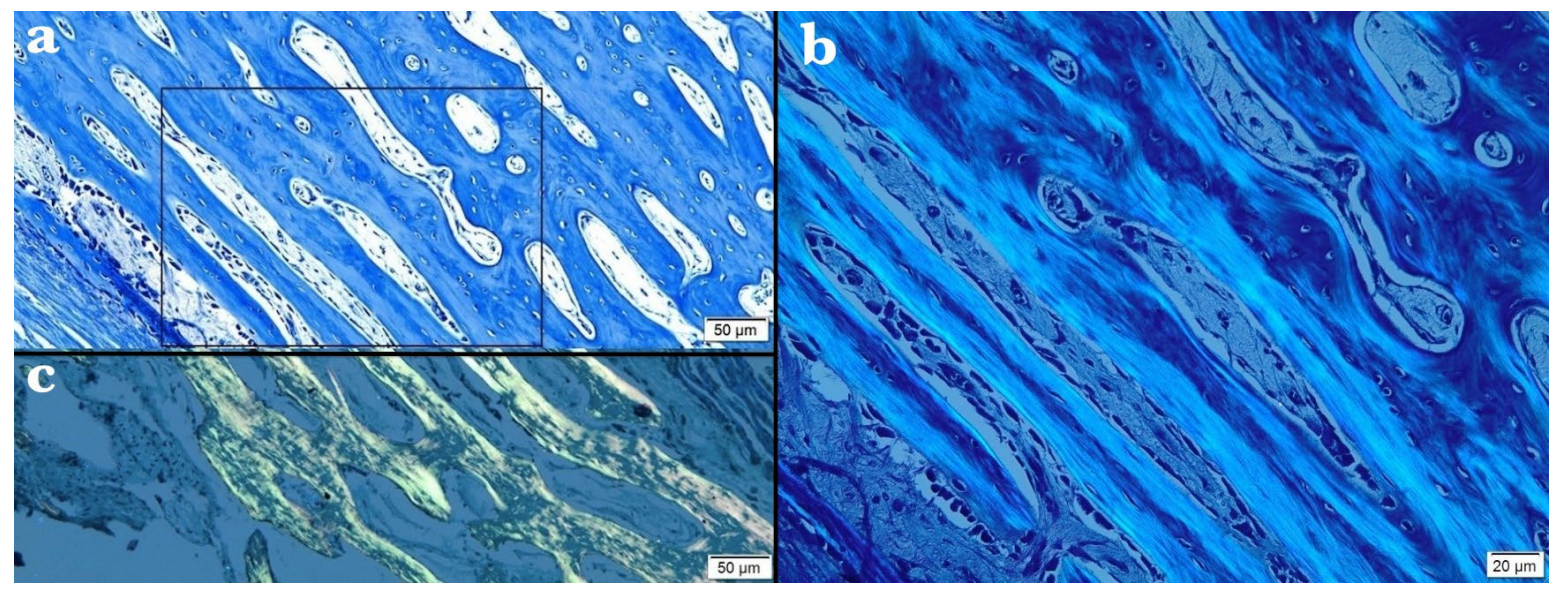

Fig. 5. Photomicrographs show matrix conformations in foetal pig and human bone with lamellar bone highlighted by polarised-light microscopy. $(\mathbf{a}, \mathbf{b})$ Photomicrographs of fibrolamellar bone from late stage foetal piglet femoral cortex are shown in longitudinal section. The same region is seen by (a) plain light microscopy (b) and polarised-light microscopy. (b) Higher magnification of the rectangle in a. Woven bone is in dark blue and lamellar bone in lighter blue. Plastic-embedded sections stained with $1 \%$ toluidine blue. (c) Representative section of human foetal tibial cortex of a 4-4 1/2 months old donor visualised by polarised-light microscopy shows a very high component of lamellar bone (yellow) that is as much as $50 \%$ in some regions. The parallel fibres are stained in light yellow as compared with dark green staining of woven bone. Paraffin-wax-embedded section were stained with safranin O/fast green. 


\section{Osteosarcoma}

The cell and matrix appearances of bone formed in highly malignant osteosarcoma lesions of the distal femur and proximal tibia were assessed in 10 adolescents (Shapiro, 1983; Shapiro and Eyre, 1982). Intra-osseous, transcortical and peri-osseous soft tissue foci in the malignant lesions elaborated a characteristic tumour osteoid matrix. Highly cellular woven bone formed from sufficiently differentiated tumour cells (Fig. 11e,f). Safranin $\mathrm{O}$-fast green staining identified the matrix as woven bone (green stain), with no red staining that would indicate chondrocyte differentiation. Regardless of the amount of woven bone produced, there was no conformational switch to lamellar bone. Owing to rapid growth of these highly malignant lesions, woven bone was synthesised continuously by the tumour mass and often spread to surround necrotic pre-existing lamellar cortical bone and metaphyseal trabeculae. Osteosarcoma lesions as well as producing woven tumour bone (osteoid), also stimulated normal reactive woven bone from the elevated periosteum at the periphery of the advancing tumour.

\section{Lacunar-canalicular appearance in woven and lamellar bone}

The lacunar-canalicular systems differed in appearance in woven and lamellar bone (Shapiro, 1988; Shapiro et al., 1995; Shapiro, 1997; Shapiro, 2016). Cell shape (within the lacunae) and cell process pattern (within the canaliculi) reflected the orientation of the collagen matrices within which they lay (Fig. 12a-e). Normal cortical osteocytes in lamellar bone were elongated and elliptical in shape and lay parallel to the longitudinal orientation of the lamellae. Cell processes passed out from the osteocyte body at regular intervals from both ends of the cell and perpendicular to its walls at regular intervals. The regularity of the lacunar-canalicular pattern conformed to the organised lamellar collagen matrix. In contrast, woven bone osteoblasts and osteocytes were round to oval, had no specific orientation to

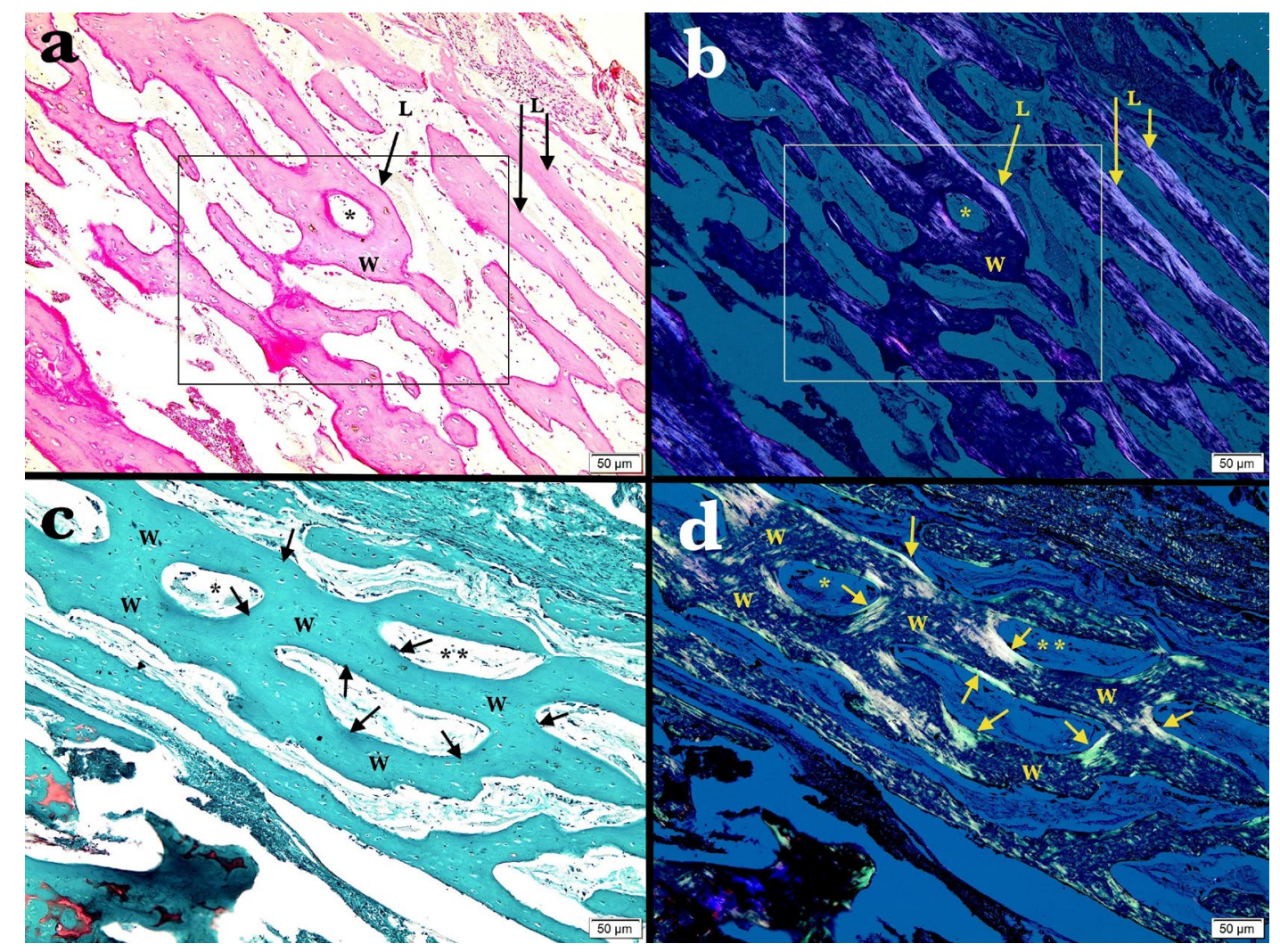

Fig. 6. Photomicrographs show paraffin-wax-embedded sections of human foetal 4-4 1/2 months old tibial cortical bone. Sections were stained $(\mathbf{a}, \mathbf{b})$ with haematoxylin and eosin and (c,d) safranin $\mathrm{O} /$ fast green. Rectangles outline the same region in $\mathbf{a}$ and $\mathbf{b}$. (a) While cellularity of the bone was evident, woven bone (W) and lamellar bone $(\mathrm{L})$ were not clearly differentiated in the haematoxylin and eosin-stained section. ${ }^{*}=$ same area in $\mathbf{a}$ and $\mathbf{b}$. (b) A polarised-light microscopy image of the region in human foetal tibia outlined in $\mathbf{a}$. Woven bone (W) is dark and lamellar bone (L) (arrows) light purple due to parallel-fibred tissue. Human foetal tibial cortical bone presented significant amounts of parallel-fibred lamellar components at 4-4 1/2 months of intrauterine development. Lamellar bone regions represented as much as $25-33 \%$ of cortical bone at this time. (c,d) Same section shown. $\mathrm{W}=$ woven bone; $\mathrm{L}=$ lamellar bone; ${ }^{*}$ and ${ }^{* *}=$ same areas. (c) Plain microscopy. Cortical bone is the central oblique strip of tissue; metaphyseal tissue and marrow are seen at lower left (red = calcified cartilage) and fibrous tissue overlying the bone is seen at upper right. (d) Polarisedlight microscopy. Arrows point to parallel-fibred lamellar tissue (yellow). Polarised light highlighted the significant amount of parallel-fibred lamellar bone (yellow, arrows) already present in young foetal tissue. 


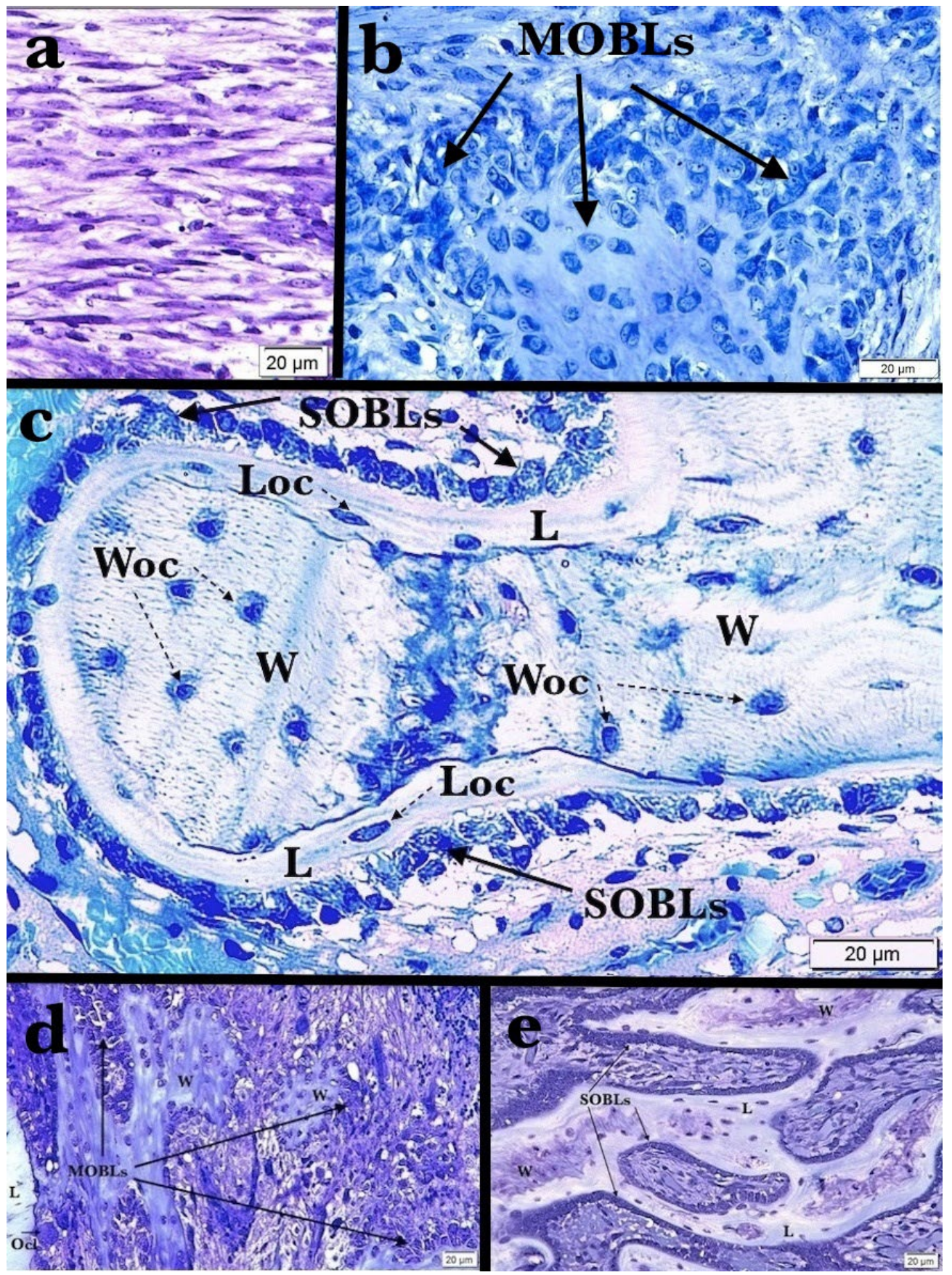

Fig. 7. Photomicrographs show range of cell and matrix appearances in bone repair. (a,e) Photomicrographs showing rabbit bone repair at different time periods after a drilling defect was made. (a,d,e) From a $2.4 \mathrm{~mm}$ unicortical femoral diaphyseal defect. $(\mathbf{b}, \mathbf{c})$ From the distraction osteogenesis model. All sections were plastic-embedded and stained with $1 \%$ toluidine blue. (a) Undifferentiated mesenchymal cells, as seen in regions undergoing early repair 1 week post surgery, were flattened and elongated with a prominent nucleus. (b) Repair tissue from the distraction osteogenesis model in a rabbit tibia at 1 week. Undifferentiated cells are in the upper left corner, with progression to MOBLs seen. Centrally, MOBLs are surrounded by minimal amounts of matrix (right arrow) but, as seen in the lower half, increasing amounts of matrix were synthesised (left arrow). (c) Histology section from bone formation site within the elongating gap in distraction osteogenesis shows a woven bone core with lamellar bone synthesis on it. W = woven bone; Woc = woven bone osteocytes; $\mathrm{L}=$ lamellar bone; Loc = lamellar bone osteocytes; Ocl = osteoclast. (d) At 2 weeks, the developing sequence of repair is seen in a $2.4 \mathrm{~mm}$ defect going from the central region (on the right) to persisting cortex (on the left). Differentiation developed from undifferentiated mesenchymal cells, to preosteoblasts, to osteoblasts surrounding themselves with woven bone. $W=$ woven bone; $L=l a m e l l a r$ bone (in persisting cortex adjacent to the defect site); Ocl = osteoclast. (e) Woven (W) and lamellar (L) bone at periphery of repair site in a rabbit $2.4 \mathrm{~mm}$ unicortical femoral diaphyseal defect at 4 weeks. 
immediately adjacent cells and their cell processes passed in irregular and random fashion through the woven matrix.

\section{Polarised-light microscopy}

Polarised-light microscopy provided a much more clear-cut definition of matrix conformation as shown in photomicrographs illustrating developing bone (Fig. 5b,c; 6b,d), fibrolamellar bone (Fig. 5b), repair bone (Fig. 8b,d) and pathological bone (Fig. 10b, 11d). Even in foetal human cortical bone, as early as 4-4 1/2 months, there was relatively abundant parallel-fibred lamellar bone on woven bone cores (Fig. 5c; 6b,d). Observation by polarised-light microscopy confirmed the abrupt change between woven and lamellar conformations with no transition zone between the two types.

\section{Histomorphometry}

Cell area/total area ratios of osteoblasts/osteocytes in woven and lamellar bone

Examples of the quantitation process in the various types of bone conformation are shown in Fig. $12 \mathrm{f}$ for woven bone, Fig. $12 \mathrm{~g}$ for both woven and lamellar bone and Fig. 12h for lamellar bone. The cell area/ total area index indicated the amount of matrix synthesised per cell. The higher the index, the greater the cellularity and the less the amount of matrix present. Samples assessed were normal human woven bone from foetal and new-born specimens, normal human lamellar bone from children and adult specimens and woven and lamellar bone specimens from patients with osteogenesis imperfecta. Normal woven bone from two foetal and two new-born individuals registered an index of $039 \pm 0.012$ (54 histological sections, 6,525 cells). Normal lamellar bone from 5 individuals, 5-40 years old, registered an index of $0.012 \pm 0.005$ (164 histological sections, 12,057 cells). In osteogenesis imperfecta, woven bone from 11 patients registered an index of $0.063 \pm 0.03$ (104 histological sections, 11,694 cells) and lamellar bone from 10 patients registered an index of $0.024 \pm 0.009$ (123 histological sections, 12,351 cells). Osteogenesis imperfecta bone was more cellular (i.e. synthesised less matrix per cell) than normal bone in both its woven and lamellar conformations

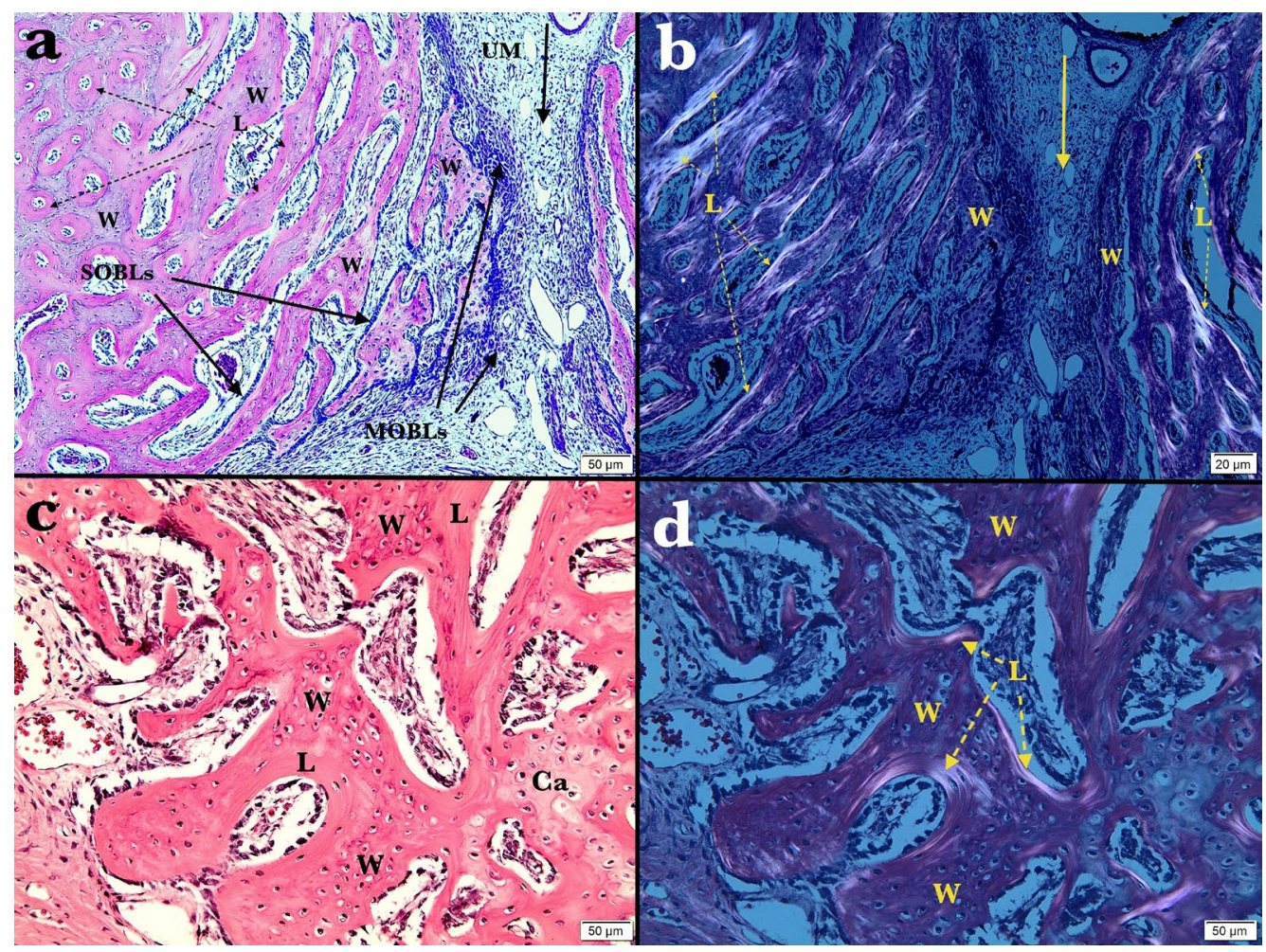

Fig. 8. Photomicrographs show bone repair in chicken and rabbit models. (a,b) Photomicrographs illustrating repair at a skeletally mature chicken humerus unicortical $3 \times 10 \mathrm{~mm}$ defect at 4 weeks. Paraffinwax-embedded sections stained with haematoxylin and eosin. Initial repair bone was at the periphery adjacent to the persisting cortex, with the central region last to repair. Solid vertical arrow at upper right = central part of defect; $\mathrm{W}=$ woven bone; $\mathrm{L}=$ lamellar bone; interrupted arrows = lamellar bone. (a) Repair was seen at 4 weeks post defect creation from the centre of the gap (on the right) to a region adjacent to the persisting cortex (on the far left). (b) Repair site illustrated with polarised-light imaging. Parallel-fibred lamellar bone appears bright yellow, while woven bone is dark. (c,d). Bone repair at site of endochondral callus in a rabbit femur treated with lower extremity cast immobilisation. Paraffin-wax-embedded sections stained with haematoxylin and eosin. (c) Repair was seen at 3 weeks. $\mathrm{Ca}=$ cartilage component of callus; $\mathrm{W}=$ woven bone; $\mathrm{L}=$ lamellar bone. (d) Polarised-light microscopy of section in $\mathbf{c}$. Lamellar bone (L) is seen as bright staining and woven bone $(\mathrm{W})$ remains dark. $\mathrm{Ca}=$ cartilage component of callus; interrupted arrows = lamellar bone. 
but lamellar osteogenesis imperfecta bone was nevertheless less cellular than woven osteogenesis imperfecta bone.

\section{Length/width ratios in woven and lamellar bone osteoblast/} osteocytes

The ratio of length to width in cortical lamellar osteocytes is $3.5: 1$. In woven bone, osteoblasts/ osteocytes recently differentiated from mesenchymal cells ratio is $1.8: 1$, consistent with their oval appearance. Once repair bone is switching to the lamellar orientation, the cells progressively change shape towards that of normal cortical osteocytes and at 4 weeks the ratio is $2.4: 1$ (Shapiro, 1988).

\section{TEM}

Woven and lamellar bone conformations were illustrated by electron microscopy in normal mouse cortical bone (Fig. 13a, b; 14a,b) and osteogenesis imperfecta bone (Fig. 14c,d). The close juxtaposition of woven and lamellar matrices was demonstrated even at high levels of resolution, with relatively abrupt transition between the two conformations (Fig. 13b). In a segment shown to be lamellar by light and polarised-light microscopy, many of the collagen fibres were oriented parallel to the long axis of the bone but others were cut in cross-section indicating an orthogonal array (Fig. 14b). The developing orthogonal array was also seen in electron micrographs from osteogenesis imperfecta bone where active surface osteoblasts synthesised collagen.

\section{Discussion}

\section{Biological significance of woven bone formation} The ability of mesenchymal osteoblasts to form woven bone de novo, at sites where no bone previously

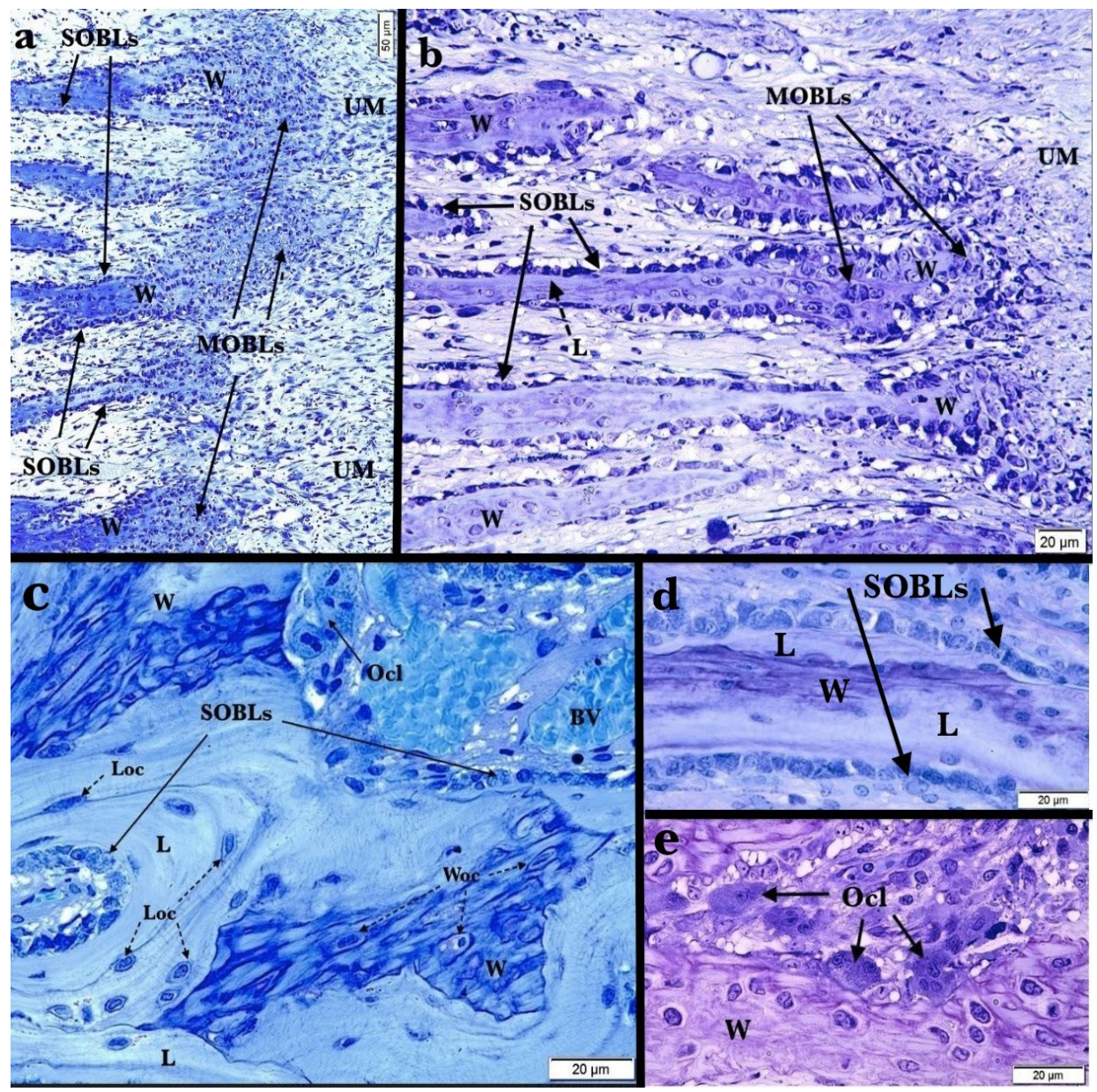

Fig. 9. Multiple photomicrographs are shown from a distraction osteogenesis model in a 3-month old rabbit tibia. All sections were plastic-embedded and stained with $1 \%$ toluidine blue. (a) Woven bone (W) formation began at the central gap region on the right and progressively increased towards one of the cut cortices (not shown) on the left. Early repair at 2 weeks at the central gap region showed tissue differentiation from undifferentiated mesenchymal cells (UM) to woven bone. (b) Higher power view closer towards one of the cut bone ends shows mesenchymal osteoblasts well and elongated woven bone (W) collections. UM = undifferentiated mesenchymal cells. (c) Lamellar bone (L) on woven bone (W) is illustrated at 4 weeks. Woc = woven bone osteocyte; Loc = lamellar bone osteocyte; Ocl = osteoclast; BV = blood vessel. Plastic-embedded sections stained with $1 \%$ toluidine blue. (d) Lengthened tissue from 4 weeks specimen. $\mathrm{W}$ = woven bone; $\mathrm{L}=$ lamellar bone. (e) Once woven bone $(\mathrm{W})$ served as a scaffold it was resorbed by multinucleated osteoclasts (Ocl, arrows). 
Table 6. Bone repair in additional experimental models inducing invariable woven to lamellar bone formation.

\begin{tabular}{|l|l|}
\hline $\begin{array}{l}\text { Bone repair following } \\
\text { full-thickness articular } \\
\text { cartilage defects into } \\
\text { subchondral bone }\end{array}$ & $\begin{array}{l}\text { Full-thickness } 2.4 \mathrm{~mm} \text { diameter articular cartilage defects were made in skeletally mature } \\
\text { rabbit proximal tibiae through underlying subchondral bone into the marrow to assess articular } \\
\text { cartilage repair. The defects induce subchondral bone repair below the articular cartilage and } \\
\text { adjacent to the epiphyseal lamellar trabecular bone (Shapiro et al., 1993). Undifferentiated } \\
\text { mesenchymal cells synthesise woven bone adjacent to the subchondral bone plate and lamellar } \\
\text { bone trabeculae. Bone repair continue in the subchondral region with SOBLs aligning on woven } \\
\text { bone to synthesise lamellar bone. }\end{array}$ \\
\hline $\begin{array}{l}\text { Bone repair following } \\
\text { transphyseal cartilage } \\
\text { defects }\end{array}$ & $\begin{array}{l}\text { Transphyseal defects through proximal tibial growth plate in immature rabbits elicit physeal } \\
\text { repair responses, as observed by magnetic resonance imaging and histology (Jaramillo et } \\
\text { al., 1990). Vascularised tissue with undifferentiated mesenchymal cells from epiphyseal and } \\
\text { metaphyseal sides migrate into the gap and MOBLs synthesise woven bone against the edges } \\
\text { of the physeal cartilage. After several days, woven bone from both regions form a transphyseal } \\
\text { bone bridge. Then, woven bone is covered by SOBLs to form a transphyseal lamellar bone bridge. }\end{array}$ \\
\hline $\begin{array}{l}\text { Bone repair following } \\
\text { induction of ischemia } \\
\text { (avascular necrosis): } \\
\text { piglet femoral head }\end{array}$ & $\begin{array}{l}\text { Avascular necrosis was induced in 3-week old piglet hips by intracapsular circumferential } \\
\text { ligature at the base of the femoral neck (Shapiro et al., 2009a). This caused complete femoral head } \\
\text { ischemia followed by repair consistent with Legg-Calvé-Perthes disease. Histological studies at } \\
\text { fragmentation stage showed vascularised mesenchymal tissue entering femoral head between } \\
\text { articular and physeal cartilage. Mesenchymal tissues differentiate to MOBLs synthesising woven } \\
\text { bone that is covered by SOBLs synthesising lamellar bone on woven scaffold. }\end{array}$ \\
\hline
\end{tabular}

existed, indicates a potent synthetic capability. Then, woven bone has a major influence on overall bone formation providing a scaffold or template on which stronger, more abundant lamellar bone is synthesised. The present study demonstrated the invariable presence of woven bone across the spectrum of vertebrate bone formation in development, repair and pathological bone disorders.

Bone has a well-ordered structural hierarchy with specific supportive functions (Lakes, 1993). Its threedimensional structure, generally presented as the specific ordering of lamellar tissue, has been assessed in detail (Cohen and Harris, 1958; Gebhardt, 1906; Ghazanfari et al., 2016; Marotti, 1993; Marotti et al., 2013; Petersen, 1930; Reznikov et al., 2014; Trelstad et al., 1976; Wagermaier et al., 2006; Weiner and Traub, 1992). Formation and maintenance of bone is due to a unique combination of cellular and molecular events interacting with biophysical influences (biophysical defined as the theories, laws and methods of physics applied to understanding biological phenomena).

\section{The mesenchymal cell and its relationship to osteoblast and osteocyte formation}

Maximow (1927) showed that undifferentiated mesenchymal cells serve as precursors for both the haematopoietic and connective tissues. He adopted the word "mesenchymal", used originally to refer to the embryonic tissue layer, for post-natal tissue descriptions and used the term "stem cell" to refer to the functional potentialities of these undifferentiated cells. The shapes of mesenchymal cells change with development due to extrinsic passive deformation from their environment, such as the fibrinous reticulum of blood clots, and intrinsic transformation based on intracellular synthesis and formation of "major processes" or protrusions (Weiss and Garber, 1952). Weiss and Garber (1952) demonstrated changes in cell shape ranging from the initial narrow elongated bipolar cells to oval or plump multipolar cells (polarity referring to the number and positioning of cell processes) as differentiation progresses. Fig. 7a shows early mesenchymal cell collections; at higher magnifications, changes to elliptical and oval shapes, with multiple cytoplasmic elongations, were seen as differentiation towards pre-osteoblasts occurred. The use of the term mesenchymal osteoblast derives from these considerations. Mesenchymal cell/stem cell function at the molecular level is being actively investigated (Kfoury and Scadden, 2015).

\section{Differing osteoblast types synthesising woven and lamellar bone}

Histological studies make it abundantly clear that initial bone matrix formation is made of woven bone, with a random array of collagen fibres synthesised across the spectrum of normal development, repair and pathological processes. This initial woven bone synthesis is performed by MOBLs. Once enough tissue has been synthesised, there is a marked change in bone cell and matrix deposition patterns as osteoblasts align in an orderly linear array on the surface of woven bone accumulations and deposit collagen matrix in an organised parallel-fibred lamellar pattern. These osteoblasts are referred to as SOBLs (Shapiro, 1988; Shapiro, 2008; Shapiro, 2016). While mesenchymal osteoblasts form woven bone where no bone previously existed, subsequent lamellar bone is formed by surface osteoblasts where there is a scaffold or template along which lamellar bone can be positioned. Most commonly, woven bone forms this scaffold, although lamellar bone can be deposited initially where other tissues provide the scaffold (Table 7).

The terms MOBLs, forming woven bone, and SOBLs, forming lamellar bone, indicate differing osteoblast functions. It is not known whether these two now clearly defined osteoblast types represent 
distinct genetic lineages or whether they stem from a single osteoblast lineage that responds in different ways to differing biophysical stimuli. There is considerable mobility of many cell precursors, including undifferentiated and early differentiating mesenchymal cells, in embryonic, developmental and repair states as they migrate to position themselves for specific roles. MOBLs actively migrate to and further differentiate at their functional sites - since they are not initially present in the limb bud and cartilage model stages of development, at repair sites immediately at time of fracture or osteotomy - and at sites of early pathological bone formation. In addition, MOBLs synthesise woven bone rapidly and de novo at sites where no bone is present. These actions are the opposite of static and are, in effect, more dynamic than the slower oriented actions of SOBLs, synthesising lamellar bone on pre-existing surfaces. SOBLs are present in the undifferentiated mesenchymal cell pool adjacent to sites of woven bone formation and simply align themselves on the surface of a woven bone scaffold once it is present

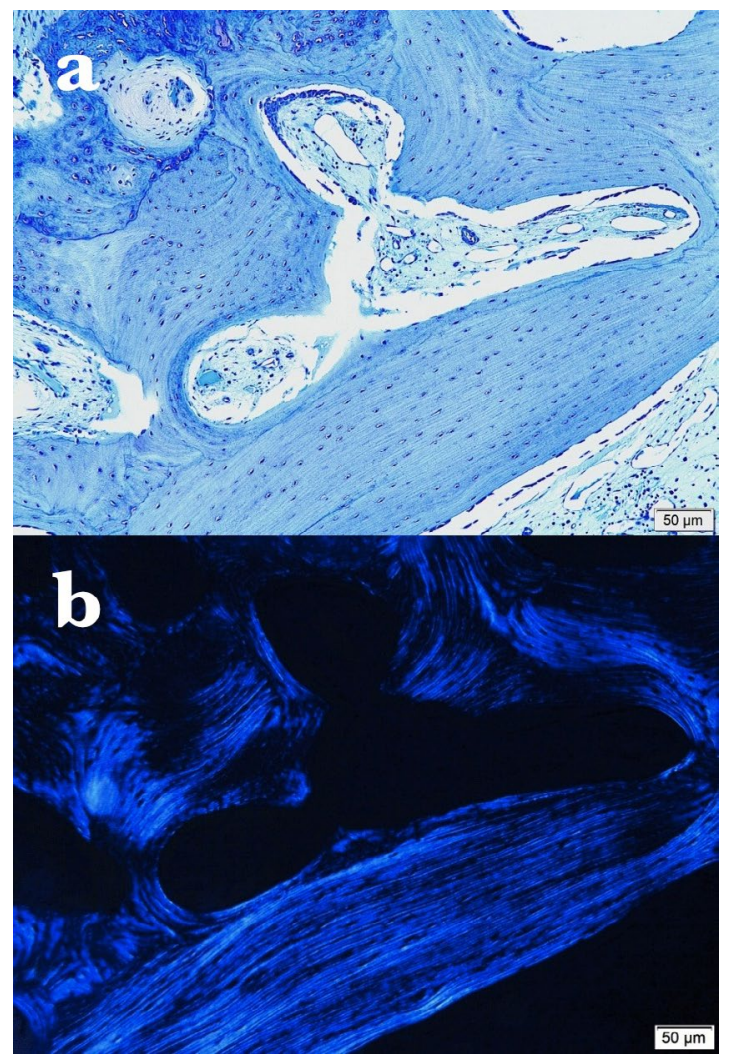

Fig. 10. Photomicrographs of osteogenesis imperfecta bone are shown. (a) Mosaic pattern of lamellar bone from tibia was evident in photomicrograph from patient with type III progressively deforming osteogenesis imperfecta, at the milder end of the spectrum. Most of the tissue was lamellar in organisation but a few areas of woven bone persisted. Plastic-embedded section stained with $1 \%$ toluidine blue. (b) Polarised-light microscopy image of the same tissue section as shown in a demonstrating the lamellar structure of bone, with parallel-fibred tissue staining bright purple. to a sufficient extent. Amprino (1947) observed that woven bone is synthesised faster than lamellar bone. This concept has been widely accepted and more recently quantified (de Margerie et al., 2002). The descriptive MOBL/SOBL terminology (compared with the static osteogenesis/dynamic osteogenesis terminology) is more consistent with understanding woven bone/lamellar bone synthesis across the entire spectrum of vertebrate bone formation. Familiarity with each set of terms is important since both refer to the concept of differing functions for the two types of osteoblasts.

\section{Bone matrix self-assembly}

Bone tissue conformation, with its repetitive pattern of woven and lamellar formation, is due to obligate self-assembly of collagen molecules in the extra-cellular space. Self-assembly, the formation of supramolecular structures by physico-chemical phenomena alone (without cellular involvement) is characterised by the spontaneous organisation of molecules into stable aggregates through noncovalent bonds under equilibrium conditions (Boncheva and Whitesides, 2005; Whitesides and Boncheva, 2002). Self-assembly is a well-defined concept (Halpern, 2002; Lehn, 2002), has been documented in many biological systems (Bard, 1992) and is particularly referable to collagen formation (Fang et al., 2013; Kadler et al., 1996; Mosser et al., 2006; O'Leary et al., 2011; Silver et al., 2003; Zhu and Kaufman, 2014). Collagen fibrils have been shown to aggregate in vitro in cell-free systems (Bouligand et al., 1985). Orthogonal arrays of collagen in lamellar bone, seen by polarised-light and electron microscopy, are additional examples of self-assembly mechanisms of matrix conformation reflecting the biophysical search for a stable conformation. In normal bone, this pattern has specific temporal and spatial features; in repair bone, the specific features are also present but are modified by the biophysical environment within which repair occurs. In pathological bone, the same specific features are also present with modifications dependent on how the specific disorder affects the amount of bone formation.

\section{Palaeohistology}

Woven bone deposition prior to parallel-fibred and lamellar bone deposition also appears to be invariable in fossil bones from multiple extinct vertebrate species, based on palaeohistology studies. For purposes of the present overview of woven bone, the most important palaeohistology contribution is the recognition of invariable woven bone formation preceding lamellar bone formation. In many mammals as well as reptiles, amphibians and birds woven bone is not only prominent in embryonic cortical bone but persists and is repetitively synthesised postnatally until skeletal maturity (Barrera et al., 2016; de Ricqlès, 1975; de Ricqlès, 1976; Francillon-Vieillot et al., 1990; Förster and Goldbach, 1954; Gross, 1934; Locke, 2004; Magal et al., 2014; Marín-Moratalla et al., 2013; 


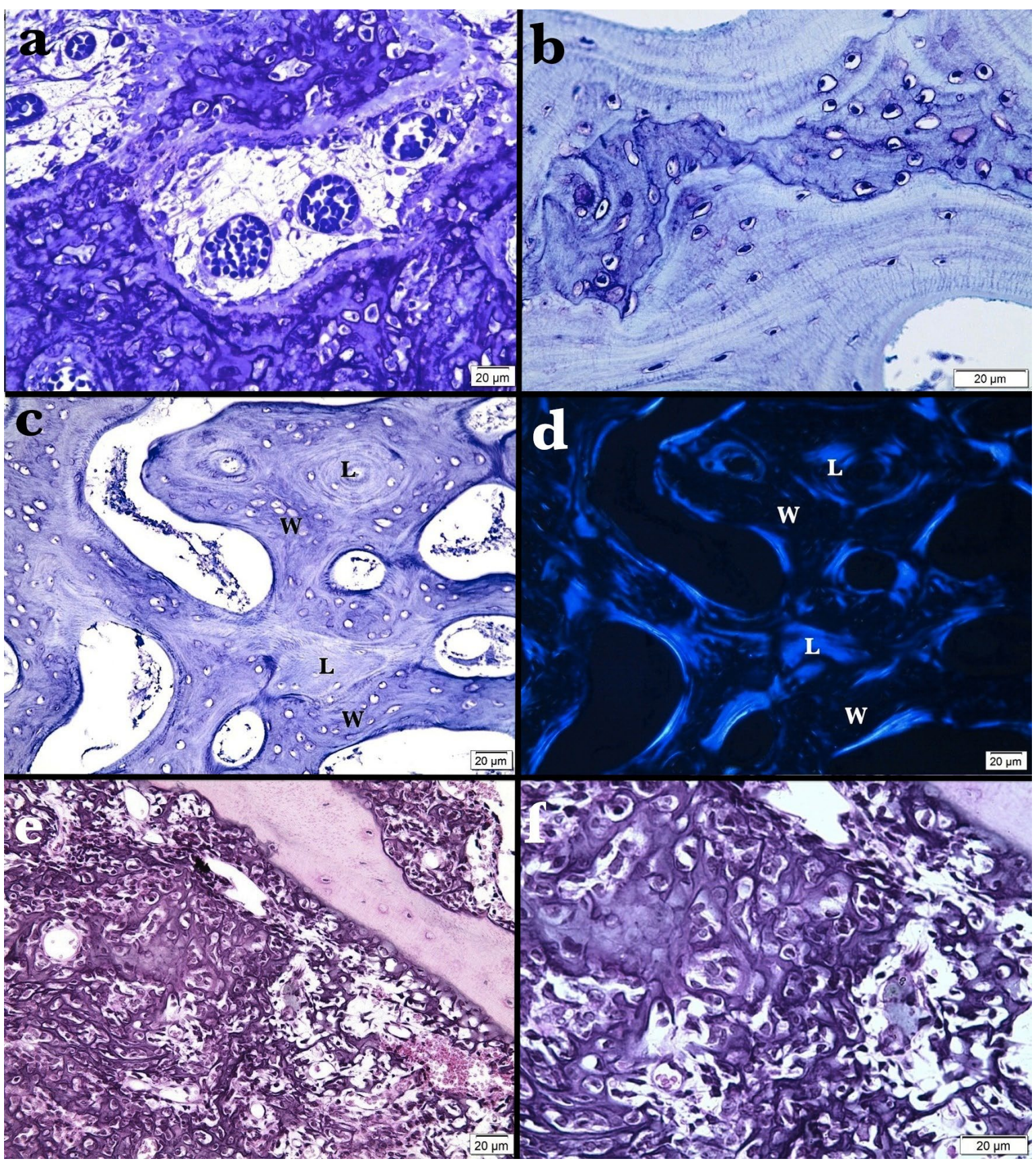

Fig. 11. Photomicrographs show osteogenesis imperfecta and osteosarcoma bone tissue. (a-d) Photomicrographs showing osteogenesis imperfecta tissue. All sections were plastic-embedded and stained with $1 \%$ toluidine blue. (a) Formation of hypercellular woven bone characterised femoral cortical bone in severely affected lethal perinatal type II osteogenesis imperfecta patient. Note the prominent vascularity (at top). (b) High power photomicrograph from a segment of deformed tibia in another patient with type III osteogenesis imperfecta showing characteristic central woven bone tissue (synthesised initially) surrounded by bone in lamellar conformation. Note the elliptical shape of the lamellar bone lacunae (osteocytes) and the regular pattern of orientation of the numerous lamellar canaliculi. (c) Lamellar bone (L) formation on woven cores (W) shown in another patient with progressively deforming type III osteogenesis imperfecta. Note differences in cellularity between the two types. (d) The same section as shown in a assessed by polarised-light microscopy; lamellar bone (L) is bright purple, with woven bone (W) collections in dark purple. (e) Tumour osteoid from a distal femoral adolescent osteosarcoma was deposited in a woven conformation. The tumour osteoid surrounded a pre-existing lamellar trabeculum, with no surface osteoblast differentiation. (f) Osteosarcoma tissue at higher magnification showing the woven nature of the osteoid. (e,f) Paraffin-wax embedded and stained with haematoxylin and eosin. 
Marín-Moratalla et al., 2014; Montoya-Sanhueza and Chinsamy, 2017; Prondvai et al., 2014; Ray et al., 2005; Stein and Prondvai, 2014).

Gross (1934) referred to fibre bone ("faserknochen") in many vertebrate species, while describing early woven and lamellar bone. de Ricqlès (1975) defined patterns of fibrolamellar, lamellar and Haversian bone that have become the standard for palaeohistology studies. Stein and Prondvai (2014) reinterpreted cortical bone structure based on studies using multi-planar sectioning and polarised-light microscopy. They felt that woven bone was more limited in amount than previously described in bone defined as fibrolamellar. They considered cortical bone tissue to be composed almost exclusively of highly organised primary bone (HOPB) consisting of both lamellar and non-lamellar components. The non-lamellar components (effectively non-osteonal) were considered to be parallel-fibred collagenous tissue rather than woven bone, based on anisotropic polarisation in differing planes and the presence of elongated elliptical-shaped lacunae characteristic of lamellar bone. Their interpretation used MOBL/ SOBL or static/dynamic osteogenesis developmental considerations, limiting woven bone designations to MOBL/static-osteogenesis-derived tissue, with all HOPB bone representing SOBL/dynamicosteogenesis-derived tissue. Then, a combined terminology was proposed defining a woven-parallel complex to recognise developmental aspects and retaining a more limited role for fibrolamellar bone (Prondvai et al., 2014). Palaeohistology definitions of cortical bone structure are summarised in Table 2 and $3 a, b$.

Woven bone in relation to bone repair models Cortical defect models

Unicortical diaphyseal rabbit and chicken models permit bone repair in a stable mechanical environment. In these models, a variable wave of tissue differentiation formed from cortex to cortex. At 3-4 weeks, histological sections showed an occasional incomplete thin rim of lamellar bone (synthesised initially on the persisting cortical scaffold), lamellar tissue osteons predominating at the site of earliest woven bone repair at the periphery of the defect (having undergone the lamellar on woven progression), collections of woven bone closer to the centre of the defect on which parallel-fibred lamellae were being deposited by SOBLs, woven bone alone synthesised by MOBLs even closer to the centre and, at the centre of the defect, undifferentiated mesenchymal cells persisted, while beginning differentiating into MOBLs. The reverse sequence was seen from the centre to the opposite cortex.

Many studies have defined the histological profile of bone formation in stable experimental environments using either plate compression of osteotomies or variable-diameter unicortical defects (Müller, 1978; Perren et al., 1969; Perren, 1979; Schenk and Willenegger, 1963; Schenk and Willenegger,
1964; Schenk and Willenegger, 1967; Schenk and Willenegger, 1977). These studies have shown how sensitive cells and matrices are to relatively subtle changes in their biophysical environment. Primary bone repair or contact healing refers to the immediate formation of lamellar repair bone by SOBLs from adjacent Haversian systems parallel to the long axis of the bone where the fragments are reduced anatomically and stabilised rigidly eliminating any interfragmentary gap. Lamellar bone repair crosses the osteotomy line without a cartilage or woven bone phase. Direct transformational bone repair or gap healing occurs in a stable environment, without a cartilage phase, where there is an interfragmentary gap of $0.2 \mathrm{~mm}$ or larger, allowing woven bone formation initially followed by lamellar bone at right angles to the longitudinal axis along the axis of vascular and mesenchymal cell invasion. Then, the lamellar bone undergoes remodelling (transformational component) to lie parallel to the Haversian systems of the long axis. The relationship of gap extent and tissue conformation is detailed in Table 7.

\section{Distraction osteogenesis}

Bone deposition in distraction osteogenesis also began adjacent to each cortex, with persistence of undifferentiated mesenchymal cells in the central gap between bone ends. Woven bone initiated repair, was elongated along the longitudinal axis with distraction and served as a scaffold for SOBLs forming trabecular and cortical bone (Fig. 9a-e) (Schuelke et al., 2018).

\section{Additional examples of invariable woven bone formation} in experimental situations

Other examples of invariable woven bone formation preceding lamellar bone formation are shown, including endochondral callus bone repair and others, as summarised in Table 6.

\section{Pathological bone formation}

Osteogenesis imperfecta

Woven/lamellar bone conformation also predominates in pathological bone formation as seen particularly well in osteogenesis imperfecta. The relative woven/ lamellar bone relationship defines the clinical severity of the disorder (Falvo and Bullough, 1973; Jaffe, 1972; Shapiro, 2016; Weber, 1930). In the lethal perinatal Sillence II variant, woven bone alone was synthesised, although in such limited amounts that parallelfibred lamellar bone was rarely seen (Fig. 11a). In severe progressively deforming variants (Sillence III), histology showed combinations of woven and lamellar bone (Fig. 11b-d). Once enough collagen has been synthesised as woven bone, subsequent new bone deposited on the woven scaffold is lamellar. The milder the involvement is, the more lamellar bone is synthesised, but woven bone cores tend to persist throughout childhood. Haversian system osteonal formation proceeds but the osteons are rarely fully compacted and the cortex is thinner than 


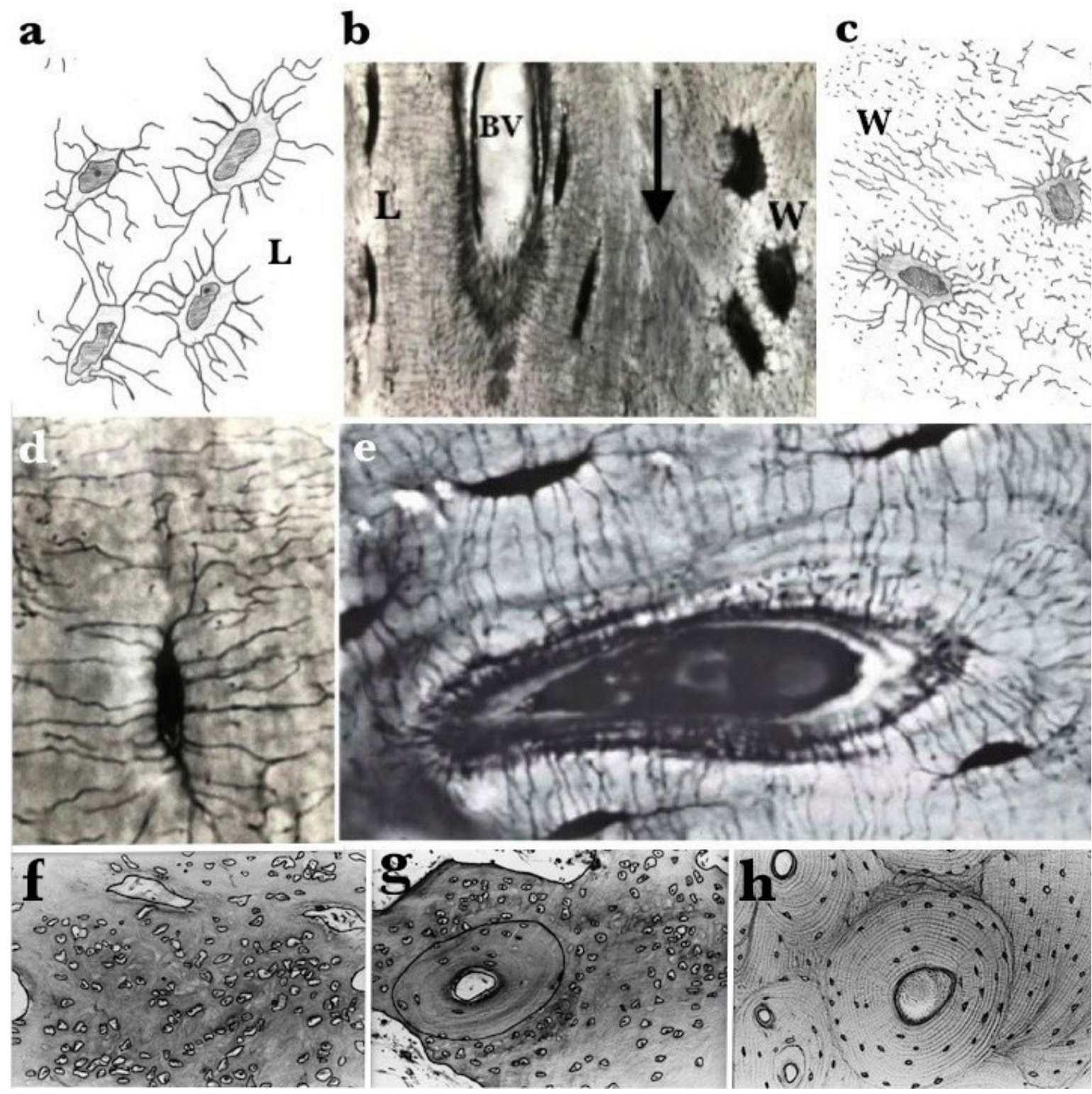

Fig. 12. Bone lacunae and canaliculi in differing matrix conformations are shown. (a) Tracings from photomicrographs of rabbit 1 week old femoral cortical bone outlining the lacunar-canalicular system in active-forming lamellar bone (L). Osteocytes were elongating and the canaliculi tended to radiate at right angles from the cell walls (interrupted arrows). A canaliculus at both ends of an osteocyte united one cell with an adjacent cell along the same long axis (solid arrow). (b) Photomicrograph of heavily stained 1 week old rabbit cortical bone showing, on the left, lamellar bone (L) around a blood vessel (BV), with flattened elongated osteocytes, with characteristic organised canaliculi parallel to and at right angles to the lengthened osteocyte lacunae reflecting their passage through the parallel-fibred lamellar matrices. On the right, woven bone $(\mathrm{W})$ osteoblasts, with randomly arrayed canaliculi. Arrow = demarcation of lamellar and woven bone. (c) Tracings of round to oval woven bone $(\mathrm{W})$ cells showing canaliculi randomly oriented reflecting their passage through the woven matrices. (d) A heavily stained single osteocyte with cell processes (lacunar/canalicular system) in lamellar bone showing the elliptical, elongated cell shape and the well-oriented canaliculi traveling within the ordered lamellar matrix. (e) Oblique section in rabbit lamellar bone showing elongated osteocytes in lamellae and their organised canaliculi linking osteocytes to lining surface osteoblasts adjacent to a central blood vessel. (b,d,e) From plastic-embedded sections stained with $1 \%$ toluidine blue. Histomorphometry at light microscopy level characterising woven and lamellar bone regarding cell area/matrix area ratios. In these examples, each cell perimeter is outlined in black. Quantitation is done on the digitising app of the microscope. $(\mathbf{f}, \mathbf{g}, \mathbf{h})$ From osteogenesis imperfecta bone. Section of (f) woven bone, (g) both woven and lamellar bone and (h) lamellar bone with osteons cut in the cross-sectional plane. The differences in cellularity were evident by simple observation but quantitation allowed for more definitive comparisons. 
normal. When assessing bone structure by histology in mild autosomal dominant osteogenesis imperfecta (Sillence I), the tissue often cannot be differentiated from the normal one, showing extensive osteonal lamellar bone and no traces of woven bone. In normal bone, cell area/total area ratios are markedly different between woven and lamellar bone, with woven bone always more cellular than lamellar bone, with less matrix per cell area. There is abrupt apposition of lamellar on woven bone with no intermediate forms seen. These observations in osteogenesis imperfecta bone support the contention that the structure of bone is an obligate phenomenon of supra-molecular organisation where self-assembly of matrices is based on biophysical rather than strictly molecular constraints. The mutations of collagen cause less matrix to be synthesised leading to persistence of immature matrix patterns.

\section{Osteosarcoma}

The earliest histopathology of osteogenic sarcoma (osteosarcoma) tissue showed what appeared to be woven bone, although it was generally referred to as tumour bone or tumour osteoid (Jaffe, 1956). Direct production of osteoid matrix by sarcomatous tumour

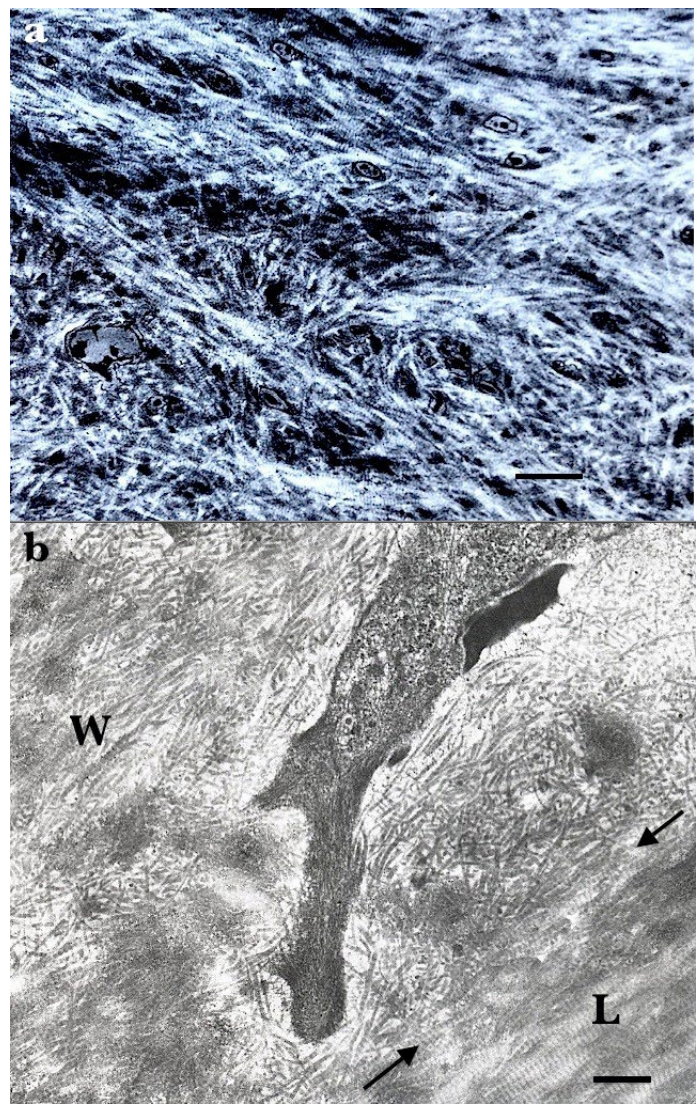

Fig. 13. Collagen appearances in woven and lamellar bone are shown by TEM. (a) Transmission electron micrograph in mouse neonatal femoral cortical bone illustrating woven bone. Collagen is seen with fibrils in random array. Scale bar: $667 \mathrm{~nm}$. (b) Transmission electron micrograph in mouse neonatal femoral cortical bone showing the juxtaposition of lamellar (L) on woven (W) bone at lower right. Scale bar: $765 \mathrm{~nm}$. cells is required to classify a lesion as an osteosarcoma. The tumour osteoid has been increasingly referred to as woven bone in descriptions and photomicrographs of osteosarcoma lesions (Czerniak, 2016a; Mirra et al., 1989). The characteristic finding with malignant neoplastic tumour bone (distinct from normal or repair bone) was the infiltration of highly cellular woven bone tissue into lamellar bone regions in uncontrolled fashion, with no tendency of SOBLs to synthesise new lamellar bone on the tumour woven bone (Fig. 11e,f). As tumour cells invade metaphyseal and cortical regions, woven tumour bone surrounds necrotic lamellar bone spicules. Mineralisation of the tumour osteoid produces radiographic sclerosis. Peripheral reactive periosteal bone in osteosarcoma lesions is woven before inducing an orderly sequence of SOBLs forming lamellar bone. Efforts are being made to determine if osteosarcoma cells are mesenchymal stem cells or osteoblast committed cells (Mutsaers and Walkley, 2014).

\section{Other pathological bone disorders}

Paget's disease of bone (osteitis deformans) occurs in adults, generally 50 years old or older. Histopathological descriptions have shown woven bone formation early in the active stages of the disorder, although eventually the predominant findings are osteoclastic bone resorption and synthesis of lamellar bone with a mosaic pattern (Dickson et al., 1945; Freund, 1929; Jaffe, 1933; Knaggs, 1925; Meunier et al., 1980; Schmorl, 1932; Seitz et al., 2009). Highly cellular collections of woven bone are prominent in benign bone tumours and other pathological bone-forming lesions such as osteoid osteoma, within the cellular fibrovascular central nidus, osteoblastoma, where the slow growing disorder allows for formation of SOBLs and lamellar bone on woven deposits (Mirra et al., 1989; Czerniak, 2016b), fibrous dysplasia (Czerniak, 2016c), secondary hyperparathyroidism (Krempien et al., 1975) and chronic osteomyelitis (Mirra et al., 1989).

\section{Classification of the stages of woven bone formation}

Based on the authors' studies reported in the present manuscript, four specific stages of woven bone formation were defined: stage I, early differentiation of pre-osteoblasts from undifferentiated mesenchymal cells; stage II, MOBLs surrounding themselves in a $360^{\circ}$ arc with randomly oriented matrix fibres; stage III, woven matrix acting as a scaffold on which SOBLs begin to synthesise bone in parallel-fibred lamellar conformation; stage IV, progressive relative diminution of woven bone in the woven bone/ lamellar bone complex. Stages II and IV are further subdivided (in $\mathrm{a}, \mathrm{b}$ and $\mathrm{c}$ ) by shifting cell area/matrix area and woven bone/lamellar bone relationships. To link woven bone formation to the entire sequence of bone tissue development, stage $\mathrm{O}$ and $\mathrm{V}$ are also defined. Stage $\mathrm{O}$ is characterised by mesenchymal cell development from undifferentiated thin, flattened 
elongated cells to progressively differentiating oval to round cells destined to form an osteoblast line. Stage V is when all bone seen in a region is lamellar. The classification is presented in Table 7.

\section{Woven and lamellar bone in relation to the two bone formation mechanisms}

Completely formed cortical and trabecular bone are considered to be the same regarding molecular components and lamellar tissue structure, even though they develop following different intramembranous and endochondral bone mechanisms. Although the final bone produced is the same, the mechanisms differ early on regarding the scaffold tissue being replaced: woven bone at the cortices during intramembranous bone formation and calcified cartilage cores at internal marrow/trabecular sites during endochondral bone formation. The role of woven bone formation, serving as a scaffold for lamellar bone deposition, is detailed in the present report but additional situations where a firm scaffold other than woven bone leads to direct lamellar bone formation were seen (Table 7; Fig. 3a-c). Woven bone was removed by osteoclasts once its role as a scaffold for lamellar bone deposition was completed. Calcified cartilage cores were also removed by osteoclasts in the process of transforming metaphyseal region trabeculae into lamellar bone (Fig. 3b,d; 9c,e).

\section{Demonstration of woven and lamellar bone}

Woven bone can be distinguished from lamellar bone (Table 4). Many of the distinctions are demonstrable by light microscopy: i) there is an abrupt transition from woven to lamellar bone, well-defined lamellar bone being deposited on collections of well-defined woven bone without the interposition of a transitional

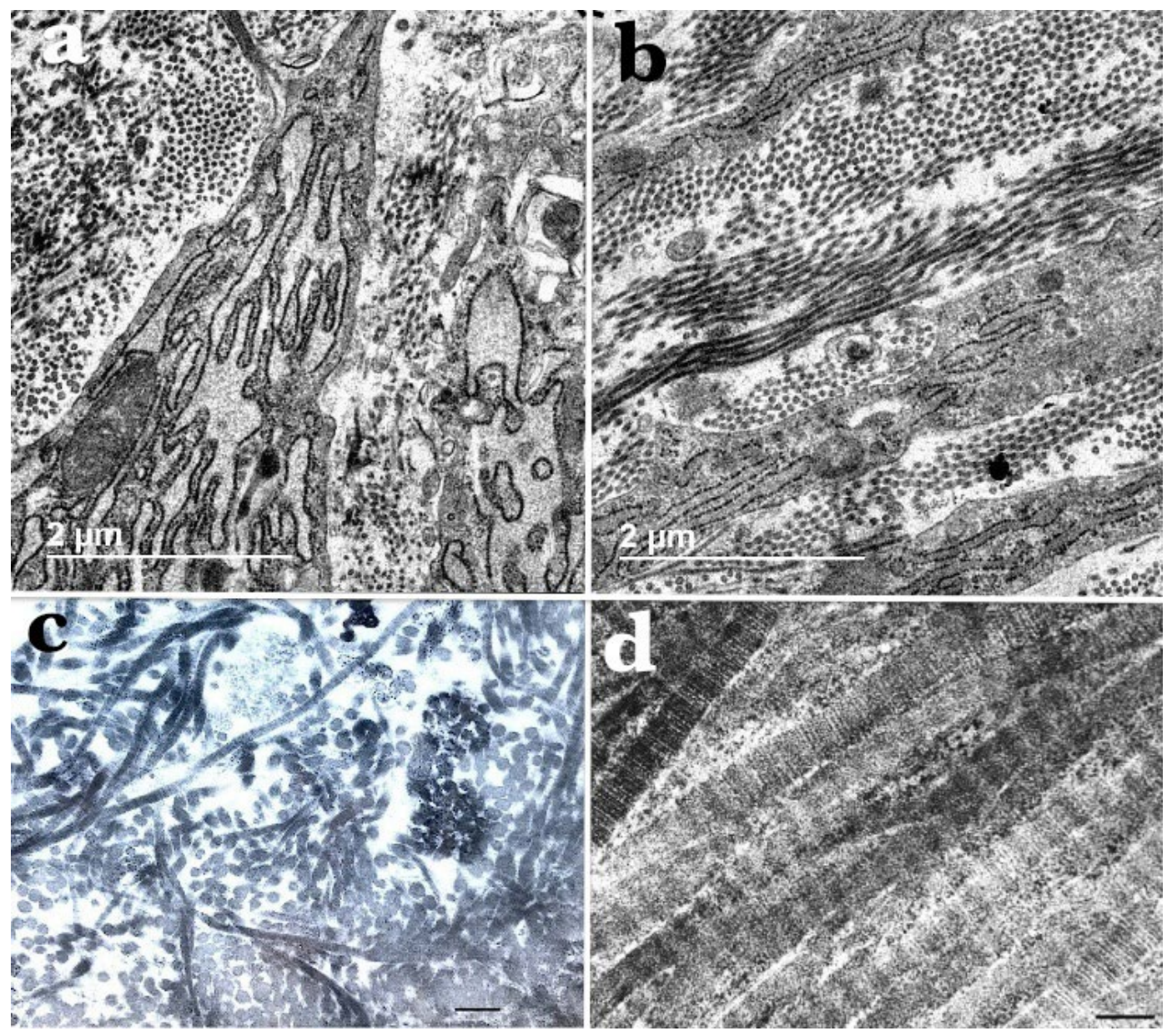

Fig. 14. Collagen appearances in woven and lamellar bone are shown by TEM. (a) TEM in mouse neonatal femoral cortical bone showing lamellar matrix in cross-section adjacent to osteoblast at right. The dilated rough endoplasmic reticulum was a structural sign of active matrix synthesis. Scale bar: $2 \mu \mathrm{m}$. (b) TEM in mouse neonatal femoral cortical bone showing osteoblasts synthesising lamellar bone alternating with bundles of parallel collagen fibres. Cells were elongated, with the long axis of the cells parallel to the lamellar orientation of the collagenous matrix. Parallel fibril groups were also in orthogonal array (at right angles to one another in alternating layers). Surface osteoblasts synthesised collagen fibrils in parallel array. The widely dilated rough endoplasmic reticulum was indicative of active collagen synthesis. Scale bar: $2 \mu \mathrm{m}$. (c,d) TEM showing matrix orientations from tissue samples of patients with osteogenesis imperfecta. (c) Woven bone matrix from a patient with type III osteogenesis imperfecta. Scale bar: $250 \mathrm{~nm}$. (d) Lamellar orientation of collagen fibrils in high magnification in bone tissue from a patient with osteogenesis imperfecta type III. Scale bar: $132 \mathrm{~nm}$. 
Table 7. Classification of stages of woven bone formation.

\begin{tabular}{|c|c|}
\hline Stage I & $\begin{array}{l}\text { Highly cellular, closely packed accumulations of differentiating pre-osteoblasts present de novo at } \\
\text { sites with no evidence of pre-existing bone tissue. These pre-osteoblasts have differentiated from the } \\
\text { undifferentiated mesenchymal-cell pool. }\end{array}$ \\
\hline Stage II & $\begin{array}{l}\text { Mesenchymal osteoblasts surround themselves in a } 360^{\circ} \text { arc with randomly oriented matrix fibres: } \\
\text { a. cell area is larger than matrix area, } \\
\text { b. cell area is equal to matrix area, } \\
\text { c. matrix area is larger than cell area. }\end{array}$ \\
\hline Stage III & $\begin{array}{l}\text { The matrix is sufficient to act as a scaffold on which surface osteoblasts begin to synthesise bone in } \\
\text { lamellar conformation. }\end{array}$ \\
\hline Stage IV & $\begin{array}{l}\text { There is progressive diminution of woven bone in the woven bone/lamellar bone complex. The } \\
\text { diminution of woven bone is relative due to the increased synthesis of lamellar bone and absolute } \\
\text { due to osteoclast resorption: } \\
\text { a. woven bone is more than lamellar bone, } \\
\text { b. woven bone is equal to lamellar bone, } \\
\text { c. lamellar bone is more than woven bone. }\end{array}$ \\
\hline Stage O/stage V & $\begin{array}{l}\text { When the entire bone tissue developmental sequence from undifferentiated mesenchymal cell to } \\
\text { exclusively lamellar bone is considered, stage } \mathrm{O} \text { is defined as encompassing mesenchymal cell } \\
\text { development from undifferentiated elongated cells to progressively differentiating oval cells, stage } \\
\text { V as when all bone seen in a region is lamellar. }\end{array}$ \\
\hline
\end{tabular}

tissue between the two; ii) the orientation of the lacunar-canalicular system provides a prominent indication of the matrix conformation it is associated with. Such distinction is valuable as a marker in palaeontology studies. Osteocytes and their lacunae in lamellar bone are elliptical and elongated and lie in the longitudinal plane of the lamellar fibres while their canaliculi are distributed in a uniform fashion passing through the matrix at right angles to the sidewalls of the lacunae. Osteoblasts/osteocytes of woven bone are round to oval and their canaliculi are randomly oriented as they pass through the woven bone matrix. Organisation of the osteocyte network mirrors the extracellular orientation in bone (Kerschnitzki et al., 2011) and osteocyte lacunae and canaliculi are well oriented in relation to the parallel collagen fibres in osteonal bone (Repp et al., 2017). Current studies assess shape modulation of osteoblast-osteocyte transformation and its relationship to matrix conformation (Dallas and Bonewald, 2010; Pazzaglia et al., 2010).

Polarised-light microscopy is essential for studies needing specific identification of woven and lamellar tissues. Human foetal bone, considered by many to be exclusively woven, has considerable amounts of parallel-fibred lamellar bone synthesised as early as 4 months of foetal life (Fig. 5c; 6b,d). Repair bone and pathological osteogenesis imperfecta bone are clearly highlighted by the technique.

Histomorphometry allows for a quantitative assessment of the lacunar-canalicular system. The American Society for Bone and Mineral Research (ASBMR) histomorphometry nomenclature has played a major role in assessing bone structure, with specific indices used for specific functions, such as bone synthesis or resorption (Dempster et al., 2013). Histomorphometry was used to create specific indices to differentiate woven from lamellar bone. A ratio that quantifies the cellularity of woven and lamellar bone helps determining if the amount of bone synthesised in relation to the cellularity bears any relationship to the recruitment of mesenchymal versus surface osteoblasts. When enough woven bone scaffold is present, it favours synthesis of lamellar bone. While further studies are being performed, in normal conditions, a bone index reaching 0.012 is associated with bone deposition in a lamellar pattern whereas an index of 0.024 is associated with lamellar deposition in osteogenesis imperfecta [Maguire et al. (2011) Osteogenesis imperfecta bone: correlation of histologic structure and radiographic appearance. American Academy of Orthopaedic Surgeons annual meeting, San Diego, CA, USA; Shapiro and Flynn, 2005].

TEM observations support matrix conformation findings apparent by light microscopy. TEM of decalcified bone demonstrates orientation of the collagen matrix and has helped determine the varying patterns of lamellar tissue orientation, such as orthogonal arrays and twisted plywood arrays (Giraud-Guille, 1988; Raspanti et al., 1996). In lamellar bone there is longitudinal and transverse fibril orientation while in woven bone a characteristic randomly arrayed fibril weave is evident. TEM of calcified sections assesses mineralisation of the collagen fibrils in the differing tissue conformations. Isolated mature apatite crystals (by TEM) are plateletlike in shape, with approximate average dimensions of 50-100 $\mathrm{nm}$ or more in length and $25-50 \mathrm{~nm}$ in width, while relatively newly deposited crystals, such as in woven bone, are considerably smaller, in the 4-6 nm thickness range (Landis et al., 1993). Mature apatite platelets are oriented approximately parallel to one another and to the collagen fibrils with which they are associated in comparison to human foetal woven bone where there are relational differences ( $\mathrm{Su}$ et al., 2003). Woven-bone-like nanocomposites have been used in assessing such aspects of bone, such as the role of cross-links in biomineralisation (Li et al., 2012). Collagen fibril orientation in lamellar bone 
in particular is well shown by scanning electron microscopy (Boyde and Hobdell, 1969; Frasca et al., 1977; Jones et al., 1975).

\section{Experimental mechanical loading models assess formation of woven bone}

Bone tissue differentiation and matrix conformation evolve under a combination of biophysical (mechanical) and molecular influences. An excellent overview has presented the features of tissue adaptation as a dynamic process using woven bone to lamellar bone formation as a prime example (Weinans and Prendergast, 1996). Currey presented the mechanical implications of tissue conformation (Currey, 1984; Currey, 2001; Currey, 2003). Mechanical-loading models in experimental animals have demonstrated that strains initially induce woven bone formation (Burr et al., 1989; Kidd et al., 2010; McKenzie and Silva, 2011a; McKenzie et al., 2011b; Rubin et al., 1995; Turner et al., 1994; Uthgenannt et al., 2007). This is rapidly followed by densification of the woven bone (more woven bone per unit area and increased calcification of the woven bone) and, then, by lamellar bone formation. Interpretation of these findings is that woven bone is a normal adaptive response to applied external mechanical strain, primarily forming on the periosteal surface. Animal experiments involved carefully measured i) strains to intact forearm bones, where the other forearm bone had transverse osteotomy alone or localised resection of bone, or ii) controlled strains that induced bending or stress fracture in one bone but not complete fracture. Mechanical-loading models are sufficiently sensitive that, depending on the extent of the loading, either woven or lamellar bone formation can be induced initially.

\section{Molecular findings accompanying woven and lamellar bone formation}

Molecular features of normal bone formation are being increasingly elucidated. These involve not only the composition of the main matrix component, collagen, but also the molecular cascades controlling mesenchymal cell differentiation and osteoblast function. Gorski (1998) pointed out probable molecular differences underlying woven and lamellar bone formation and histological studies confirm this separation of osteoblast functionality. Posttranslational assessment of collagen fibrillogenesis has been effectively studied in tissue culture and can be adapted for specific questions (Gerstenfeld et al., 1993). There is an extensive literature on the molecular composition of normal and repair bone formation. Most studies refer to early presence of woven bone and eventual predominance of lamellar bone (Claes et al., 2012; Einhorn and Gerstenfeld, 2015; Franz-Odendaal et al., 2006; Franz-Odendaal, 2011). Certain molecules have been identified as concentrated at certain temporal stages of bone formation and inferred as being associated with woven (early) or lamellar (later) bone formation without, however, being specifically related to any particular structural conformation. Studies also have identified molecular characteristics of the close interplay between osteogenesis and angiogenesis (Percival and Richtsmeier, 2013). Mechanical loading models inducing bone formation have compared the temporal expression of molecular constituents of woven and lamellar bone. McKenzie et al. (2011b) identified 395 genes differentially expressed between woven and lamellar bone $1 \mathrm{~h}$ after loading, with 5,883 and 5,974 genes expressed on days 1 and 3, respectively. Microarray analysis grouped these changes into initial inflammatory, followed by vascular response, osteogenesis and bone remodelling genes. These stages are also identified in histological studies outlined in the present review. These studies have demonstrated the ability to correlate histological cell accumulations with molecular concentrations. Many studies have outlined molecular associations with normal and repair bone development at different time periods; although, these studies have not separated woven from lamellar bone. The terms were based on the assumption that earlier bone had higher woven and more mature bone higher lamellar components.

Studies on the molecular nature of woven versus lamellar bone would benefit from specific assessments of known molecules that play important roles but are present in extremely small amounts not generally recognisable on gene screening studies. Such possibly important molecules in woven bone formation are some of the "minor" collagens, such as types III and $\mathrm{V}$, and intermolecular collagen crosslinks. Collagen crosslink formation is characterised by developmental changes as collagen matures (Eyre et al., 2008; Knott and Bailey, 1998; Hanson and Eyre, 1996; RodriguezPascual and Slatter, 2016). The crosslinks affect the strength of collagen fibrils (Garnero et al., 2006) as well as the rate and type of their mineralisation (Wassen et al., 2000). No studies have assessed them in relation to woven and lamellar bone, to the authors' knowledge. Recent technical advances, such as laser capture microdissection, allow localised and specific correlation of structural histological findings with associated molecular components. This methodology has been used extensively in assessing the molecular biology of tumours (Bertos and Park, 2016). Lasercapture microdissection and microarray analysis have also been valuable identifying molecules in the same tissues at different sites. In the distal mouse femur, Shapiro et al. (2009b) compared hypertrophic zone chondrocytes of the secondary ossification centre to hypertrophic chondrocytes of the physis at the same structural stage of development and demonstrated differences in the molecular profile. There are specific structural/histological features of woven and lamellar bone as well as a demonstrated sequence of woven to lamellar bone formation. Much valuable understanding can come from localised 
molecular assessments of immediately adjacent cell concentrations, such as MOBLs and SOBLs, even though both are defined in newly forming bone as osteoblasts. It will be interesting to determine whether expression of different molecules in the matrices of woven and lamellar bone simply reflect an invariable temporal sequence of initial bone formation (woven) followed by later bone formation (lamellar) or whether the differences are specific for woven bone and lamellar bone conformations, regardless of a temporal sequence.

\section{Conclusions}

The ubiquitous presence of woven bone in vertebrates has a great biological significance. Woven bone precedes and induces more mature lamellar bone formation. It has two major functions, serving as an active nidus initiating bone formation de novo at sites where no previous bone exists and as a scaffold on which lamellar bone is synthesised. Mesenchymal osteoblasts and early woven bone must contain high concentrations of molecular factors directing cell differentiation into bone-forming lines.

Studies of bone formation increasingly recognise differing osteoblast populations associated with the two matrix conformations, woven and lamellar. It is not known whether these two osteoblast types represent distinct genetic lineages or whether they stem from a single osteoblast lineage that responds differently to differing biophysical stimuli.

Osteoblasts of woven bone, referred to as MOBLs, are surrounded in a $360^{\circ}$ arc with randomly arrayed collagen bundles; osteoblasts of lamellar bone, referred to as SOBLs, are aligned linearly on woven bone surfaces (or adjacent pre-existing lamellar bone or metaphyseal calcified cartilage) to synthesise parallel-fibred lamellar bone. While all osteoblasts are derived from mesenchymal cells, the term mesenchymal osteoblast was chosen to indicate initial bone formation de novo in a cellular mass where no bone previously existed, as would occur in the mesenchyme of classical embryological terminology. The term surface osteoblast was chosen to describe the striking linear cellular alignment.

The term static osteogenesis describes MOBLs forming woven bone, while dynamic osteogenesis describes SOBLs forming lamellar bone. The two lines of osteoblast function are both active processes resulting from undifferentiated mesenchymal cell movements. MOBLs differentiate from the mesenchymal tissue mass to synthesise woven bone de novo where no previous bone existed. SOBLs differentiate from the mesenchymal tissue mass to synthesise lamellar bone becoming positioned in a linear array once a surface scaffold is present.

Woven bone is synthesised more rapidly than lamellar bone.

Bone tissue formation from initial woven to eventual lamellar matrix conformation follows a repetitive obligate self-assembly pattern in all vertebrates in normal, repair and pathological states.

Synthesis of lamellar bone on woven bone is an abrupt distinct occurrence; gradual intermediate tissue deposition from woven to lamellar bone is not seen.

Six major histological features distinguish woven from lamellar bone.

Lamellar bone structure varies in different vertebrates. In human and some larger mammalian cortices, secondary osteons (Haversian systems) predominate but many species have cortical fibrolamellar or woven-parallel complex bone in plexiform or reticular patterns with some primary but few or no secondary osteons.

The study has allowed for a classification of woven bone development from stage I to stage IV. Stage O was also defined as encompassing mesenchymal cell development from undifferentiated thin, flattened elongated cells to progressively differentiating oval to round shaped pre-osteoblast cells. Stage V defines when all bone in a region is lamellar.

Once woven bone has formed, it quickly serves as a scaffold for synthesis of lamellar bone. Woven bone infrequently exists alone in large accumulations; it invariably becomes covered by SOBLs and parallelfibred lamellar bone and exists as a woven-lamellar, fibro-lamellar or woven-parallel-fibred complex.

Woven bone is removed by osteoclasts once its role as a scaffold for lamellar bone deposition is completed.

Intramembranous and endochondral bone formation mechanisms synthesise bone that is ultimately lamellar, with the same molecular constituents; the mechanisms differ regarding the scaffold tissue being replaced: woven bone at the cortices (intramembranous) and calcified cartilage (endochondral) at internal marrow trabeculae.

Correlative studies using laser capture microdissection, microarray analysis and other evolving technologies allow for specific isolation of MOBLs/static osteogenesis/woven bone and SOBLs/dynamic osteogenesis/lamellar bone and determination of their gene/molecular profiles.

\section{Acknowledgements}

Portions of this work were performed at the Stanford Nano Shared Facilities (SNSF)/Stanford Nanofabrication Facility (SNF) and supported by the National Science Foundation under award ECCS1542152.

\section{References}

Amprino R (1947) La structure du tissu osseux envisagée comme expression de différences dans la vitesse de l'accroissement. Arch Biol 58: 315-330. 
Bard J (1992) Morphogenesis. The cellular and molecular processes of developmental biology. Cambridge University Press, Cambridge, UK.

Barrera JW, Le Cabec A, Barak MM (2016) The orthotropic elastic properties of fibrolamellar bone tissue in juvenile white-tailed deer femora. J Anat 229: 568-576.

Bertos NR, Park M (2016) Laser capture microdissection as a tool to study tumor stroma. Methods Mol Biol 1458: 13-25.

Bidder A (1906) Osteobiologie. Arch f Mikroskop Anat 68: 137-213.

Biedermann W (1914) Physiologie der Stütz- und Skelettsubstanzen in Handbuch der Vergleichenden Physiologie. Ed: Winterstein H, $3^{\text {rd }}$ volume, $1^{\text {st }}$ half, $1^{\text {st }}$ part, section XI. Das Knochengewebe. Jena, Verlag von Gustav Fischer. pp: 1085-1188.

Boncheva M, Whitesides GM (2005) Making things by self-assembly. MRS Bulletin 30: 736-742.

Bouligand Y, Denfle JP, Lechaire JP, Maillard M (1985) Twisted architecture in cell-free assembled collagen gels: study of collagen substrates used for cultures. Biol Cell 54: 143-162.

Boyde A, Hobdell MH (1969) Scanning electron microscopy of lamellar bone. Zeitsch $\mathrm{f}$ Zellforsch 93: 213-231.

Buckwalter JA, Glimcher MJ, Cooper RR, Recker R (1995) Bone biology. Part I: structure, blood supply, cells, matrix, and mineralization. J Bone Joint Surg Am 77: 1256-1275.

Burger EH, Klein-Nuland J (1999) Mechanotransduction in bone-role of the lacunocanalicular network. FASEB J 13: S101-S112.

Burr DB, Schaffler MB, Yang KH, Lukoschek M, Sivaneri N, Blaha JD, Radin EL (1989) Skeletal change in response to altered strain environments: is woven bone a response to elevated strain? Bone 10: 223-233.

Claes L, Recknagel S, Ignatius A (2012) Fracture healing under healthy and inflammatory conditions. Nat Rev Rheumatol 8: 133-143.

Cohen J, Harris WH (1958) The three-dimensional anatomy of haversian systems. J Bone Joint Surg Am 40: 419-434.

Cooper RR, Milgram JW, Robinson RA (1966) Morphology of the osteon. An electron microscopic study. J Bone Joint Surg Am 48: 1239-1271.

Currey JD (1960) Differences in the blood-supply of bone of different histological types. Quart J Microscop Sci 101: 351-370.

Currey J (1984) Mechanical adaptations of bones. Princeton University Press, Princeton NJ, USA.

Currey JD (2001) Ontogenetic changes in compact bone material properties. In: Bone Mechanics Handbook, $2^{\text {nd }}$ edition. Ed: Cowin SC. CRC Press, Boca Raton FL, USA. Chapter 19. pp: 19-1 to 19-16.

Currey JD (2003) The many adaptations of bone. J Biomech 36: 1487-1495.

Czerniak B (2016a) Osteosarcoma. In: Dorfman and Czerniak's Bone Tumors, $2^{\text {nd }}$ edition, Elsevier/ Saunders, Philadelphia, PA, USA. Chapter 5. pp: 200-355.
Czerniak B (2016b) Benign osteoblastic tumors. In: Dorfman and Czerniak's Bone Tumors, $2^{\text {nd }}$ edition, Elsevier/Saunders, Philadelphia PA, USA. Chapter 4. pp: 144-199.

Czerniak B (2016c) Fibrous dysplasia and related lesions. In: Dorfman and Czerniak's Bone Tumors, $2^{\text {nd }}$ edition, Elsevier/Saunders, Philadelphia, PA, USA. Chapter 8. pp: 570-616.

Dallas SL, Bonewald LF (2010) Dynamics of the transition from osteoblast to osteocyte. Ann NY Acad Sci 1192: 437-443.

de Margerie E, Cubo J, Castanet J (2002) Bone typology and growth rate: testing and quantifying 'Amprino's rule' in the mallard (Anas platyrhynchos). CR Biol 325: 221-230.

de Ricqlès A (1975) Recherches paléohistologiques sur les os longs des tétrapodes. VII.-Sur la classification, la signification fonctionelle et l'histoire des tissus osseux des tétrapodes. Première partie. Annales de Paléontologie (Vertébrés) 61: 51-129.

de Ricqlès AJ (1976) On bone histology of fossil and living reptiles, with comments on its functional and evolutionary significance. In: Morphology and Biology of Reptiles. Ed: Bellairs A, Cox CB. Linnean Society Symposium Series, Academic Press, New York, NY, USA. Number 3. pp: 123-151.

de Ricqlès A, Bourdon E, Legendre LJ, Cubo J (2016) Preliminary assessment of bone histology in the extinct elephant bird Aepyornis (Aves, Palaeognathae) from Madagascar. CR Palevol 15: 197-208.

Dempster DW, Compston JE, Drezner MK, Glorieux FH, Kanis JA, Malluche H, Meunier PJ, Ott SM, Recker RR, Parfitt AM (2013) Standardized nomenclature, symbols, and units for bone histomorphometry: a 2012 update of the report of the ASBMR histomorphometry nomenclature committee. J Bone Miner Res 28: 1-16.

Dickson DD, Camp JD, Ghormley RK (1945) Osteitis deformans: Paget's disease of the bone. Radiology 44: 449-470.

Einhorn TA, Gerstenfeld LC (2015) Fracture healing: mechanisms and interventions. Nat Rev Rheumatol 11: 45-54.

Enlow DH (1962) Functions of the Haversian system. Am J Anat 110: 269-305.

Enlow DH, Brown SO (1956) A comparative histological study of fossil and recent bone tissues. Part I. Texas J Sci 8: 405-443.

Enlow DH, Brown SO (1957) A comparative histological study of fossil and recent bone tissues. Part II. Texas J Sci 9: 186-214.

Enlow DH, Brown SO (1958) A comparative histological study of fossil and recent bone tissues. Part III. Texas J Sci 10: 187-230.

Eyre DR, Weis MA, Wu JJ (2008) Advances in collagen cross-link analysis. Methods 45: 65-74.

Falvo KA, Bullough PG (1973) Osteogenesis imperfecta: a histometric analysis. J Bone Joint Surg Am 55: 275-286.

Fang M, Goldstein EL, Matich EK, Orr BG, Banaszak Holl MMB (2013) Type I collagen self- 
assembly: the roles of substrate and concentration. Longmuir 29: 2330-2338.

Ferretti M, Palumbo C, Contri M, Marotti G (2002) Static and dynamic osteogenesis: two different types of bone formation. Anat Embryol 206: 21-29.

Foote JS (1916) A contribution to the comparative histology of the femur. Smithsonian Contributions to Knowledge. Ed: Hrdlicka A. Smithsonian Institution, Washington, DC, USA. Volume 35. Number 3. pp: 1-230.

Förster A, Goldbach HJ (1954) Die histologische differenzierung von femurdiaphysen neugeborener, kleinkinder und kleiner haustiere. Dtsch Z gerichtl Med 43: 273-289.

Francillon-Vieillot $\mathrm{H}$, de Buffrénil $\mathrm{V}$, Castanet J, Géraudie J, Meunier FJ, Sire JY, Zylberberg L, de Ricqlès A (1990) Microstructure and mineralization of vertebrate skeletal tissues. In: Skeletal Biomineralization: Patterns, Processes and Evolutionary Trends. Ed: Carter JG. Van Nostrand Reinhold, New York, NY, USA. 1: 471-530.

Franz-Odendaal TA (2011) Induction and patterning of intramembranous bone. Front Biosci (Landmark Ed) 16: 2734-2746.

Franz-Odendaal TA, Hall BK, Witten PE (2006) Buried alive: how osteoblasts become osteocytes. Dev Dyn 235: 176-190.

Frasca P, Harper RA, Katz JL (1977) Collagen fiber orientations in human secondary osteons. Acta Anat 98: 1-13.

Freund E (1929) Zur Frage der Ostitis deformans Paget. Virchows Archiv Path Anat 274: 1-36.

Frost HM (1960) Observations on fibrous and lamellar bone. Henry Ford Hosp Med Bull 8: 199-207.

Garnero P, Borel O, Gineyts E, Duboeuf F, Solberg H, Bouxsein ML, Christiansen C, Delmas PD (2006) Extracellular post-translational modifications of collagen are major determinants of biomechanical properties of fetal bovine cortical bone. Bone 38: 300309.

Gebhardt W (1906) Ueber funktionell wichtige Anordnungsweisen der feineren und groberen Baulemente des Wirbeltierknochens. II. Spezieller Teil, 1. Der Bau der Haversschen Lamellensystems und seine funktionelle Bedeutung. Arch Entwickl Organ 20: 187-322.

Gegenbauer C (1864) Ueber die Bildung des Knochengewebes. Jena Zeit f Med Naturwissen 1: 343-369.

Gegenbauer C (1867) Ueber die Bildung des Knochengewebes. Jena Zeit f Med Naturwissen 3: 206-246.

Gerstenfeld LC, Riva A, Hodgens K, Eyre DA, Landis WJ (1993) Post-translational control of collagen fibrillogenesis in mineralizing cultures of chick osteoblasts. J Bone Miner Res 8: 1031-1043.

Ghazanfari S, Khademhosseini A, Smit TH (2016) Mechanisms of lamellar collagen formation in connective tissues. Biomaterials 97: 74-84.

Giraud-Guille MM (1988) Twisted plywood architecture of collagen fibrils in human compact bone osteons. Calcif Tiss Int 42: 167-180.
Giraud-Guille M-M, Besseau L, Martin R (2003) Liquid crystalline assemblies of collagen in bone and in vitro systems. J Biomech 36: 1571-1579.

Glimcher MJ, Shapiro F, Ellis RD, Eyre DR (1980) Changes in tissue morphology and collagen composition during the repair of cortical bone in the adult chicken. J Bone Joint Surg Am 62: 964-972.

Gorski JP (1998) Is all bone the same? Distinctive distributions and properties of non-collagenous matrix proteins in lamellar vs. woven bone imply the existence of different underlying osteogenic mechanisms. Crit Rev Oral Biol Med 9: 201-223.

Gross W (1934) Die Typen des mikroskopischen Knochenbaues bei fossilen Stegocephalen und Reptilien. Zeit Anat Entwicklung 103: 731-764.

Halpern J (2002) Reaching across the sciences. Proc Natl Acad Sci U S A 99: 4762.

Hanson DA, Eyre DR (1996) Molecular site specificity of pyridinoline and pyrrol cross-links in type I collagen of human bone. J Biol Chem 271: 26508-26516.

Havers C (1691) Osteologia Novo. Smith, London, UK.

Jaffe HL (1929) The structure of bone. With particular reference to its fibrillar nature and the relation of function to internal architecture. Arch Surg 19: 24-52.

Jaffe HL (1933) Paget's disease of bone. Arch Path 15: 83-131.

Jaffe HL (1956) Osteogenic sarcoma of bone. Clin Orthop 7: 27-40.

Jaffe HL (1972) Metabolic, degenerative, and inflammatory diseases of bones and joints. Lea and Febiger, Philadelphia, PA, USA.

Jaramillo D, Shapiro F, Hoffer FA, Winalski CS, Koskinen MF, Frasso R, Johnson A (1990) Post traumatic growth-plate abnormalities: MR imaging of bony-bridge formation in rabbits. Radiology 175: 767-773.

Jones SJ, Boyde A, Pawley JB (1975) Osteoblasts and collagen orientation. Cell Tiss Res 159: 73-80.

Kadler KE, Holmes DF, Trotter JA, Chapman JA (1996) Collagen fibril formation. Biochem J 316: 1-11.

Kerschnitzki M, Wagermaier W, Roschger P, Seto J, Shahar R, Duda GN, Mundlos S, Fratzl P (2011) The organization of the osteocyte network mirrors the extracellular matrix orientation in bone. J Struct Biol 173: 303-311.

Kfoury Y, Scadden DT (2015) Mesenchymal cell contributions to the stem cell niche. Cell Stem Cell 16: 239-253.

Kidd LJ, Stephens AS, Kuliwaba JS, Fazzalari NL, Wu ACK, Forwood MR (2010) Temporal pattern of gene expression and histology of stress fracture healing. Bone 46: 369-378.

Knaggs RL (1925) On osteitis deformans (Paget's disease) and its relation to osteitis fibrosa and osteomalacia. Br J Surg 13: 206-237.

Knott L, Bailey AJ (1998) Collagen cross-links in mineralizing tissues: a review of their chemistry, function, and clinical relevance. Bone 22: 181-187. 
Kölliker A (1853) Of the osseous system. In Manual of Human Histology. Ed: Busk G, Huxley T. Sydenham Society, London, UK. 1: 289-388.

Kölliker A (1886) Der feinere Bau des Knochengewebe. Zeit f Wissen Zool. 44: 644-680.

Krempien B, Geiger G, Ritz E (1975) Structural changes of cortical bone in secondary hyperparathyroidism. Replacement of lamellar bone by woven bone. Virchows Arch A Path Anat Histol 366: 249-256.

Lakes R (1993) Materials with structural hierarchy. Nature 361: 511-515.

Landis WJ, Song MJ, Leith A, McEwen L, McEwen BF (1993) Mineral and organic matrix interactions in normally calcifying tendon visualized in three dimensions by high-voltage electron microscopic tomography and graphic image reconstruction. J Struct Biol 110: 39-54.

Lehn JM (2002) Toward complex matter: supramolecular chemistry and self-organization. Proc Natl Acad Sci U S A 99: 4763-4768.

Li Y, Thula TT, Jee S, Perkins SL, Aparicio C, Douglas EP, Gower LB (2012) Biomimetic mineralization of woven bone-like nanocomposites: role of collagen cross-links. Biomacromolecules 13: 49-59.

Locke M (2004) Structure of long bones in mammals. J Morph 262: 546-565.

Magal RA, Reznikov N, Shahar R, Weiner S (2014) Three-dimensional structure of minipig fibrolamellar bone: adaptation to axial loading. J Struct Biol 186: 253-264.

Marín-Moratalla N, Jordana X, Köhler M (2013) Bone histology as an approach to providing data on certain key life history traits in mammals: implications for conservation biology. Mamm Biol 78: 422-429.

Marín-Moratalla N, Cubo J, Jordana X, MoncunillSolé B, Köhler M (2014) Correlation of quantitative bone histology data with life history and climate: a phylogenetic approach. Biol J Linn Soc 112: 678-687.

Marotti G (1993) A new theory of bone lamellation. Calcif Tissue Int 53 (Suppl 1): S47-S56.

Marotti G (2010) Static and dynamic osteogenesis. Ital J Anat Embryol 115: 123-126.

Marotti G, Ferretti M, Palumbo C (2013) The problem of bone lamellation: an attempt to explain different proposed models. J Morph 274: 543-550.

Maximow AA (1927) Morphology of the mesenchymal reactions. Arch Path 4: 557-606.

McKenzie JA, Silva MJ (2011a) Comparing histological, vascular and molecular responses associated with woven and lamellar bone formation induced by mechanical loading in the rat ulna. Bone 48: 250-258.

McKenzie JA, Bixby EC, Silva MJ (2011b) Differential gene expression from microarray analysis distinguishes woven and lamellar bone formation in the rat ulna following mechanical loading. PLoS ONE 6 (12): e29328. DOI: 10.1371/journal.pone.0029328.
Meunier PJ, Coindre JM, Edouard CM, Arlot ME (1980) Bone histomorphometry in Paget's disease. Quantitative and dynamic analysis of Pagetic and non-Pagetic bone tissue. Arth Rheum 23: 1095-1103.

Mirra JM, Gold RH, Picci P (1989) Osseous tumors of intramedullary origin. In: Bone Tumors. Clinical, radiologic, and pathologic correlations. Ed: Mirra JM, Picci P, Gold RH. Lea and Febiger, Philadelphia, PA USA. Volume 1, chapter 7. pp: 143-430.

Montoya-Sanhueza G, Chinsamy A (2017) Long bone histology of the subterranean rodent Bathyergus suillus (Bathyergidae): ontogenetic pattern of cortical bone thickening. J Anat 230: 203-233.

Mosser G, Anglo A, Helary C, Bouligand Y, Girard-Guille M-M (2006) Dense tissue-like collagen matrices formed in cell-free conditions. Matrix Biol 25: 3-13.

Müller ME (1978) Bases expérimentales et principes de l'ostéosynthèse par compression. Int Orthop 2: 115-125.

Mutsaers AJ, Walkley CR (2014) Cells in osteosarcoma: mesenchymal stem cells or osteoblast committed cells? Bone 62: 56-63.

O'Leary LER, Fallas JA, Bakota EL, Kang MK, Hartgerink JD (2011) Multi-hierarchical self-assembly of a collagen mimetic peptide from triple helix to nanofibre and hydrogel. Nature Chem 3: 821-828.

Pazzaglia UE, Congiu T, Marchese M, Dell'Orbo C (2010) The shape modulation of osteoblast-osteocyte transformation and its correlation with the fibrillar organization in secondary osteons. A SEM study employing the graded osmic maceration technique. Cell Tissue Res 340: 533-540.

Percival CJ, Richtsmeier JT (2013) Angiogenesis and intramembranous osteogenesis. Dev Dynam 242: 909-922.

Perren SM (1979) Physical and biological aspects of fracture healing with special reference to internal fixation. Clin Orthop Relat Res 138: 175-196.

Perren SM, Russenberger M, Steinemann S, Müller ME, Allgöwer M (1969) The reaction of cortical bone to compression. Acta Orthop Scand Supp 125: 19-30.

Petersen H (1930) Die organe des skeletsystems. In Handbuch der Mikrokopischen Anatomie des Menschen. Ed: von Möllendorff W. $2^{\text {nd }}$ volume, Die Gewebe. $2^{\text {nd }}$ part, Stützgewebe, Knochengewebe, Skeletsystem, Springer, Berlin, Germany. pp:520-678.

Prondvai E, Stein KHW, De Ricqlès A, Cubo J (2014) Development-based revision of bone tissue classification: the importance of semantics for science. Biol J Linn Soc 112: 799-816.

Quekett J (1849a) On the intimate structure of bone, as composing the skeleton in the four great classes of animals, viz., mammals, birds, reptiles and fishes. Trans Microscop Soc London 2: 46-58.

Quekett J (1849b) Additional observations on the intimate structure of bone. Trans Microscop Soc London 2: 59-64.

Raspanti M, Guizzardi S, Strocchi R, Ruggeri A (1996) Collagen fibril patterns in compact bone: 
preliminary ultrastructural observations. Acta Anat 155: 249-256.

Ray S, Chinsamy A, Bandyopadhyay S (2005) Lystrosaurus Murrayi (Therapsida, dicynodontia): bone histology, growth and lifestyle adaptations. Palaeontology 48: 1169-1185.

Repp F, Kollmannsberger P, Roschger A, Berzlanovich A, Gruber GM, Roschger P, Wagermaier W, Weinkamer R (2017) Coalignment of osteocyte canaliculi and collagen fibers in human osteonal bone. J Struct Biol 199: 177-186.

Reznikov N, Shahar R, Weiner S (2014) Bone hierarchical structure in three dimensions. Acta Biomater 10: 3815-3826.

Rivas R, Shapiro F (2002) Structural stages in the development of the long bones and epiphyses. A study in the New Zealand white rabbit. J Bone Joint Surg (Am) 84: 85-100.

Rodriguez-Pascual F, Slatter DA (2016) Collagen cross-linking: insight on the evolution of metazoan extracellular matrix. Sci Rep 6: 37374. DOI: 10.1038/ srep37374.

Rubin CT, Gross TS, McLeod KJ, Bain SD (1995) Morphologic stages in lamellar bone formation stimulated by a potent mechanical stimulus. J Bone Miner Res 10: 488-495.

Schenk R, Willenegger H (1963) Zur histologischen Bild der sogenannten Primärheilung der Knochenkompakta nach experimentellen Osteotomien am Hund. Experientia 19: 593-595.

Schenk R, Willenegger H (1964) Zur histologie der primären Knochenheilung. Langenbeck's Arch Klin Chir 308: 440-452.

Schenk RK, Willenegger HR (1977) Zur histologie der primären Knochenheilung. [Histology of primary bone healing: modifications and limits of recovery of gaps in relation to extent of the defect.] Unfallheil 80: 155-160.

Schenk R, Willenegger H (1967) Morphological findings in primary fracture healing. Symp Biol Hungaricae 7: 75-86.

Schmorl G (1932) Über ostitis deformans Paget. Virchows Archiv 283: 694-751.

Schuelke J, Meyers N, Reitmaier S, Klose S, Ignatius A, Claes C (2018) Intramembranous bone formation after callus distraction is augmented by increasing axial compressive strain. PLoS One 13: e0195466. DOI: 10.1371/journal.pone.0195466.

Segmüller G (1966) Bone repair and internal fixation. Prog Surg 5: 87-122.

Seitz S, Priemel M, Zustin J, Beil FT, Semler J, Minne H, Schinke T, Amling M (2009) Paget's disease of bone: histologic analysis of 754 patients. J Bone Miner Res 24: 62-69.

Shapiro F (1983) Ultrastructural observations on osteosarcoma tissue. A study of ten cases. Ultrastruct Pathol 4: 151.

Shapiro F (1985) Consequences of an ostegenesis imperfecta diagnosis for survival and ambulation. J Pediatr Orthop 5: 456-462.
Shapiro F (1988) Cortical bone repair: the relationship of the lacunar-canalicular system and gap junctions to the repair process. J Bone Joint Surg Am 70: 1067-1081.

Shapiro F (1997) Variable conformation of gap junctions linking bone cells: a transmission electron microscopic study of linear, stacked linear, curvilinear, oval and annular junctions. Calcif Tissue Int 61: 285-293.

Shapiro F (2008) Bone development and its relation to fracture repair. The role of mesenchymal osteoblasts and surface osteoblasts. Eur Cells Mater 15: 53-76.

Shapiro F (2016) Pathobiology and treatment of dysplasias, physeal fractures, length discrepancies, and epiphyseal and joint disorders. In: Pediatric Orthopedic Deformities. $2^{\text {nd }}$ edition. Developmental Bone Biology, Springer Publishing International, New York, NY, USA. Volume 1. Chapter 1. pp: 1-158.

Shapiro F, Eyre DR (1982) Collagen polymorphism in extracellular matrix of human osteosarcoma. J Natl Cancer Inst 69: 1009-1016.

Shapiro FD, Holtrop M, Glimcher MJ (1977) Organization and cellular biology of the perichondrial ossification groove of Ranvier. J Bone Joint Surg 59: 703-723.

Shapiro F, Rand F, Upton J, Barone L (1992) Histologic patterns of bone formation in rabbit distraction osteogenesis. Orthop Trans 16: 561-562.

Shapiro F, Koide S, Glimcher MJ (1993) Cell origin and differentiation in the repair of full-thickness defects of articular cartilage. J Bone Joint Surg Am 75: 532-553.

Shapiro F, Cahill C, Malatantis G, Nayak RC (1995) Transmission electron microscopic demonstration of vimentin in rat osteoblast and osteocyte cell bodies and processes using the immunogold technique. Anat Rec 241: 39-48.

Shapiro F, Connolly S, Zurakowski D, Menezes N, Olear E, Jimenez M, Flynn E, Jaramillo D (2009a) Femoral head deformation and repair following induction of ischemic necrosis. Histologic and magnetic resonance imaging study in the piglet. J Bone Joint Surg Am 91: 2903-2914.

Shapiro F, Flynn E, Calicchio ML (2009b) Molecular differentiation in epiphyseal and physeal cartilage. Prominent role for gremlin in maintaining hypertrophic chondrocytes in epiphyseal cartilage. Biochem Biophys Res Commun 390: 570-576.

Silver FH, Freeman JW, Seehra GP (2003) Collagen self-assembly and the development of tendon mechanical properties. J Biomech 36: 1529-1553.

Smith JW (1960a) Collagen fibre patterns in mamalian bone. J Anat 94: 329-344.

Smith JW (1960b) The arrangement of collagen fibres in human secondary osteones. J Bone Joint Surg Br 42: 588-605.

Stein K, Prondvai E (2014) Rethinking the nature of fibrolamellar bone: an integrative biological revision of sauropod plexiform bone formation. Biol Rev 89: 24-47. 
Su X, Sun K, Cui FZ, Landis WJ (2003) Organization of apatite crystals in human woven bone. Bone 32: 150-162.

Todd RB, Bowman W (1845) The Physiological Anatomy and Physiology of Man. Volume 1, chapter 5, JW Parker, London, UK. pp: 97-125.

Tomes J, De Morgan C (1853) Observations on the structure and development of bone. Phil Trans Roy Soc London 143: 109-139.

Trelstad RL, Hayashi K, Gross J (1976) Collagen fibrillogenesis: intermediate aggregates and superfibrillar order. Proc Natl Acad Sci U S A 73: 4027-4031.

Turner CH, Forwood MR, Rho J-Y, Yoshikawa T (1994) Mechanical loading thresholds for lamellar and woven bone formation. J Bone Miner Res 9: 87-97.

Uthgenannt BA, Kramer MH, Hwu JA, Wopenka B, Silva MJ (2007) Skeletal self-repair: Stress fracture healing by rapid formation and densification of woven bone. J Bone Miner Res 22: 1548-1556.

Van Dijk FS, Sillence DO (2014) Osteogenesis imperfecta: clinical diagnosis, nomenclature and severity assessment. Am J Med Genet 164: 1470-1481.

Von Ebner V (1875) Ueber den feineren Bau der Knochensubstanz. Sitzungsb Akad Wissensch 71-72: 49-138.

Wagermaier W, Gupta HS, Gourrier A, Burghammer M, Roschger P, Fratzl P (2006) Spiral twisting of fiber orientation inside bone lamellae. Biointerphases 1: 1-5.

Wassen MHM, Lammens J, Tekoppele JM, Sakkers RJB, Liu Z, Verbout AJ, Bank RA (2000) Collagen structure regulates fibril mineralization in osteogenesis as revealed by cross-link patterns in calcifying callus. J Bone Miner Res 15: 1776-1785.

Weber M (1930) Osteogenesis imperfecta congenita. A study of its histopathogenesis. Arch Pathol 9: 984-1006.

Weidenreich F (1930) Das Knochengewebe. In Handbuch der Mikrokopischen Anatomie des Menschen, ed W von Möllendorff. $2^{\text {nd }}$ volume, Die Gewebe. $2^{\text {nd }}$ part, Stützgewebe, Knochengewebe, Skeletsystem, Springer, Berlin, Germany. pp: 391-520.

Weinans H, Prendergast PJ (1996) Tissue adaptation as a dynamical process far from equilibrium. Bone 19: 143-149.

Weiner S, Traub W (1992) Bone structure: from ångstroms to microns. FASEB J 6: 879-885.
Weiss W, Garber B (1952) Shape and movement of mesenchyme cells as functions of the physical structure of the medium. Contributions to a quantitative morphology. Proc Natl Acad Sci U S A 38: 264-280.

Whitesides GM, Boncheva M (2002) Beyond molecules: self-assembly for mesoscopic and macroscopic components. Proc Natl Acad Sci U S A 99: 4769-4774.

Zhu J, Kaufman LJ (2014) Collagen I self-assembly: revealing the developing structures that generate turbidity. Biophys J 106: 1822-1831.

\section{Discussion with Reviewers}

Daniel Youngstrom: Do mesenchymal and surface osteoblasts represent discrete lineage states or are they functional definitions based primarily on the ultrastructure of the associated bone matrix?

Authors: Mesenchymal and surface osteoblasts are currently functional terms based on their specific and unique association with woven and lamellar bone conformations, respectively. As indicated in Conclusions, it is not known whether these two osteoblast types represent distinct genetic lineages or whether they stem from a single osteoblast lineage that responds differently to differing biophysical stimuli. Isolation of the two groups of osteoblasts for molecular analyses, which is difficult but now technically feasible, should help answer the question.

Daniel Youngstrom: What, if anything, is known about the cell/molecular basis of the abrupt transition from woven to lamellar bone?

Authors: The abrupt transition from woven to lamellar bone is observed invariably using a light microscope and at the ultrastructural level. While woven bone serves as a scaffold for surface osteoblasts, as do calcified cartilage cores in the metaphyses, we are not aware of investigations as to the biophysical or molecular events underlying this occurrence.

Editor's note: The Scientific Editor responsible for this paper was Martin Stoddart. 